\title{
EFFECT OF KAOLIN AND DIATOMS ON GROWTH, PRODUCTIVITY AND PESTS OF POTATO UNDER NORTH SINAI CONDITIONS
}

\author{
Soubeih, Khaled A. ${ }^{1}$, Essam A. Ali ${ }^{2 *}$ and Abeer E. El-Hadidy ${ }^{2}$ \\ ${ }^{1}$ Plant Production Department, Desert Research Center, El-Matareya, \\ Cairo, Egypt \\ ${ }^{2}$ Plant protection Department, Desert Research Center, El-Matareya, \\ Cairo, Egypt \\ *E-mail: essamnewaaa@yahoo.com
}

$\mathrm{T}$

he effect of kaolinite and diatom sediments (DS) were applied as crud natural products for soil addition at rates of 2.5 and 5 ton/fed and/or as commercially products for foliar spraying these products are kaolin (Super Nano) and diatoms forms at concentrations of 2.5 and $5 \%$ against some potato pests as insects leafminer fly (Liriomyza huidobrensis), and aphid (Myzus persica) as well as disease early blight caused by Alternaria solani, also to study their effect on growth, plant leaves area $\left(\mathrm{cm}^{2}\right)$ and fresh and dry weight/plant as well as, leaves area index (LAI) and net assimilation rat (NAR) in addition to chlorophyll content measured after 45 and 75 days from sowing, yield and its components (tubers number/plant, average of tuber fresh weight and yield/plant, plot and feddan) as compared with traditional agricultural practices on potato crop (Solanum tuberosum L.) Daimond variety. The experiment was carried out under the desert conditions (Eastern part of Al-Ismailia governorate within Sinai) in split block design. The results cleared that the diatoms and kaolin (Super Nano) as foliar spraying were the superior effect at $5 \%$ concentration on cumulative leafminer, aphid infestations and early blight disease incidence and severity. The highest reduction of soil additive treatment against leafminer insect was obtained from diatom sediments (DS) at 5 ton/fed, followed by diatom sediments (DS) at $2.5 \mathrm{ton} / \mathrm{fed}$. In case of aphid leaves infestations as soil additives, the highest reduction was (DS) at 5 ton/fed followed by kaolinite at 5 ton/fed. The most effective soil additive to reduce incidence and severity of early blight disease was obtained from diatom sediments (DS) at 5 ton/fed, followed by kaolinite at 5 ton/fed. The interaction between soil additives and foliar spraying decreased significantly infestation with leafminer, aphid and early blight disease. The most effective treatment was 
achieved from the interaction between soil additives (DS at 5 ton/ fed) $\times$ foliar spraying (diatoms $5 \%$ or super Nano $5 \%$ ) to reduce leafminer and aphid infestations and incidence and severity of early blight disease. Diatom at 5\% as foliar spraying or/and (DS) at rate of 5 ton/fed as soil additive, which had significant positive response to plant growth and chlorophyll content as well as yield and its component. High significant positive correlations were found between potato yield and either plant leaves area, NAR, no. of tuber/plant and average of tuber weight. Regression coefficients indicated that for each increase of one tuber/plant, yield of potato correspondingly increased by 3.64 ton/fed.

Keywords: Potato, kaolinite, diatom sediments, leafminer insects, aphid, early blight disease, growth, productivity

Potato (Solanum tuberosum L.) is the fourth most cultivated crop as one of the most important tuber staple cash crops around the world and (FAO, 2012 and Jalali, 2013). Potato is one of Egyptian strategic vegetable crops occupping an advanced rank among the crops of local and export consumption. Pests and pathogenic diseases are the most important impediments which determine spread potato cultivation and decrease the production in Upper Egypt and Delta regions. The loss in production ranged between $15-60 \%$ and may reach $100 \%$ in the field and $10-20 \%$ after harvest (Van der Walls et al., 2001 and Abdel-Razek et al., 2014). Potato crop plants are susceptible to many insect pests such as the leafminer fly (Liriomyza huidobrensis Blanchard). Potato tuber moth (Phthorimaea operculella Zeller) and aphids (Kroschel et al., 2013). Recently, leafminer larvae have become an economically important pest of potato. The larvae of leafminer fly feeds on the leaf mesophyll tissue, furthermore, these wounding also allows entry of bacterial and fungal diseases (Bueno et al., 2007 and Palumbo, 2012). Aphids (M. persicae Sulzer) are the most important pest than attack all organs of potato plants, especially young and soft parts (Edward and David, 2002). The economically aphides damaging is done through sucking the plant cells juices; secrete a sugary liquid that stimulates black sooty mold growth cover the surface of leaves which reduce sunlight absorbing (Qureshi, 2014); aphids also transmit different viruses disease to potato which results in high yield loss (Maketon et al., 2008). Potato plants are infected with early blight disease caused by (Alternaria solani Sorauer) that, is the most economically important foliage diseases, which survive in leaf or stem tissues on or in the soil (Van der Walls et al., 2001). This disease challenges a wide range of Solanaceous plants over a wide range of climatic conditions, often resulting in a complete defoliation of plant. The disease initially appears on the older leaves causing premature senescence and leaf area reduction. The fungus causes stem canker or collar rot of young 
seedlings, sunken spots or cankers on older stems, blossom drop and loss of young fruits and dark leathery fruit spots, usually about the point of attachment of decayed lesions may form on the tubers, permitting the entrance of decay organisms on potato. In severe attacks, lesions appear on upper stems and petioles (Raziq and Ishtiaq, 2010).

Pests and disease control by using industrial of chemical products resulted in resistance of some pests and pathogen to conventional insecticides and fungicides, in addition to the negative impacts in human health and environment. Also, more than 540 insect species are resistant to synthetic insecticides (Vincent et al., 2003).

Kaolinite is one of clay minerals with formula $\mathrm{Al}_{2} \mathrm{Si}_{2} \mathrm{O}_{5}(\mathrm{OH})_{5}$ has chemically inert over a wide range of $\mathrm{pH}$ and a low exchangeable captain capacity (1-16 meq/100g) (Brown et al., 2010). Many investigators used kaolin as novel biological control material, which creates a protective mechanical barrier against plant pathogenic diseases and approach to suppressing arthropods, diptera, homopterous, trips and aphides after sprayed on the plant surface as particle film (Lamb et al., 2002; Liang and Liu, 2002; Reitz et al., 2008 and Crooks and Prentice, 2011). In this respect, Gindaba and Wand (2007) reported that kaolin particle film application on apple trees was achieved vary inconsistently in its effect on leaf temperature and photosynthetic rate. While, Steiman and Bittenbender (2007) observed that kaolin spraying on glass slides reduced photosynthetically active radiation, UV transmission and the temperature of glass surface. Glenn et al. (2010) found that using kaolin as particle film application increased leaf water potential and decreased stomatal conductance. However, kaolin at concentration of $6 \%$ in treated soybean plants decreased node number, stem height, stem diameter, number of seeds and number of pods per plant, weight of seed, biological yield, seed yield and harvest index but the number of seeds per pod was not affected (Javan et al., 2013). Also, Mohadeseh et al. (2013) found that sprayed kaolin on wheat at concentrations of $3.75 \%$ increased grain yield and decreased aphid damage while $1.25 \%$ kaolin treatment resulted in the highest biological yield.

Diatoms (Bacillariophyceae) are microscopic unicellular algae found in both freshwater and marine environments. Many species of diatoms are found floating in the surface layers of the water in almost all aquatic habitats; they are key components of food webs in nearly all freshwater and saline environments (Dixit et al., 1992). Cell walls are composed primarily of biogenic silica $(\mathrm{SiO})$ or opaline silica $\left(\mathrm{SiO}_{2} \cdot \mathrm{nH}_{2} \mathrm{O}\right)$ consisting of two interlocking, box-like halves, one larger than the other (the thecae) (CanterLund and Lund, 1995). Many diatoms have specific optima and tolerance for a range of environmental variables and therefore shifts in e.g. salinity, $\mathrm{pH}$, nutrient concentrations or temperature are likely to result in changes in species composition which are due to characteristics of diatoms (Battarbee et al., 2001). Diatoms are used in many industries like toothpastes, agricultural 
chemicals, fertilizers, polishes, catalyst carriers, porcelain (Mann and Stickle, 1997). Diatoms were investigated as pest management, because they are very rich in silica $(85 \%)$ which composed of amorphous silica $\left(\mathrm{SiO}_{2}\right)$ (Laing et al., 2006). Silicon is an agronomic ally beneficial eliminate as it confers rigidity strength and resistance against pests and diseases; improves water economy by reducing transportation rate; alleviates the ill effects of abiotic stresses and enhances any crop yield (Vasanthi et al., 2014). Diatoms is used as insecticide that has a different mode of action in terms of its action on insect exoskeleton but diatomaceous earth is powdered remains of fossilized diatoms and has extremely small but sharp protrusions that severely injure insects when they crawl over it (Sarwar, 2016).

Crooks and Prentice (2011) found that Diatoms, which are prepared commercially with milling process produced glass-like product used as spray or dust. The product can scratch an insect's exoskeleton or puncture gut linings making them less tolerant of environmental conditions in addition, releasing the diatoms cells compounds to plant leaves (Linker et al., 2000).

The aim of this work is to study the effects of natural products such as kaolin and diatoms as foliar spraying or /and soil additives against potato insect pests (leafminer fly and aphid), early blight disease, improving plant growth, yield and quality of potato plants (Solanum tuberosum L.) under newly reclaimed desert land.

\section{MATERIALS AND METHODS}

The factorial trails were carried out in Al-Kantara Sharq experimental station located $30049^{\prime} 41.4^{\prime \prime} \mathrm{N}$ and $32^{\circ} 24^{\prime} 11.4^{\prime \prime} \mathrm{S}$, Eastern part of Al-Ismailia governorate within Sinai to evaluate the effects of kaolin $\mathrm{SN}$ and diatoms products as foliar spraying and soil additives on potato plants. Two factors were tested, the first included five foliar treatments, control, low pressure spraying kaolin (Super Nano) at concentration of 0, 2.5 and $5.0 \%$ and diatoms at $0,2.5$ and $5.0 \%$, while the second factor involved control (without addition), crud kaolinite at rates of 2.5 and 5.0 ton/fed and diatoms sediments (DS) at rates of 2.5 and 5.0 ton/fed as soil additions.

Traditional agricultural practices of potato Daimond cv. have been done like soil tilling before and after the poultry manure addition and recommended dose of mineral fertilizers supply (90-60-75 units of NPK during growing season). Drip irrigation system used, the soil ridged $60 \mathrm{~cm}$ apart between one and another, drip irrigation hoses (GR 4L/h) were extended, the experimental field divided into 5 blocks each of it $3.5 \mathrm{~m}$ width and $15 \mathrm{~m}$ length, every block splitted to 5 plots with $3.5 \times 3 \mathrm{~m}\left(10.5 \mathrm{~m}^{2}\right)$, the experiment repeated 4 replicates, the treatments were randomly distributed, where foliar spraying in blocks while soil additives within plots. Soil treatments were done before planting. Splatted potato tubers Daimond cv. were sown on February $2^{\text {nd }} 2014$ and 2015 early summer seasons, ridges 30

Egyptian J. Desert Res., 67, No. 1, 83-115 (2017) 
$\mathrm{cm}$ apart between halls. The foliar spraying was applied after 15 days from $75 \%$ of seedling emerged and repeated every 2 weeks twice.

Physical and chemical analyses of the experimental soil were carried out according to the methods described by Piper (1950) and Jackson (1962), respectively, while irrigation water analysis was determined by methods of Richards (1954) as shown in tables (1,2 and 3).

Table (1). Mechanical properties of the experimental soil.

\begin{tabular}{ccccccc}
\hline Seasons & $\begin{array}{c}\text { Soil } \\
\text { depth } \\
(\mathbf{c m})\end{array}$ & $\begin{array}{c}\text { Coarse } \\
\text { sand }\end{array}$ & $\begin{array}{c}\text { Fine } \\
\text { sand }\end{array}$ & $\begin{array}{c}\text { Silt } \\
\text { \% }\end{array}$ & Clay & $\begin{array}{c}\text { Class } \\
\text { Texture }\end{array}$ \\
\hline $1^{\text {st }}$ & $0-40$ & 29.33 & 46.51 & 14.65 & 9.51 & Sandy loam \\
$2^{\text {nd }}$ & 06.89 & 49.83 & 13.02 & 10.26 & Sandy loam \\
\hline
\end{tabular}

Table (2). Chemical analysis of the experimental soil.

\begin{tabular}{|c|c|c|c|c|c|c|c|c|c|c|c|c|}
\hline \multirow{3}{*}{ Seasons } & \multirow{3}{*}{$\begin{array}{c}\text { Soil } \\
\text { depth } \\
(\mathbf{c m})\end{array}$} & \multirow{3}{*}{ pH } & \multirow{3}{*}{$\begin{array}{l}\text { EC } \\
\text { dS/ } \\
\text { m }^{2}\end{array}$} & \multirow{3}{*}{$\begin{array}{c}\mathrm{CaCO}_{3} \\
(\%)\end{array}$} & \multicolumn{8}{|c|}{ Saturation soluble extract } \\
\hline & & & & & \multicolumn{4}{|c|}{ Soluble anions (ppm) } & \multicolumn{4}{|c|}{ Soluble Cations (ppm) } \\
\hline & & & & & $\mathrm{CO}_{3}$ & $\mathrm{HCO}_{3}$ & $\mathrm{SO}_{4}{ }^{-2}$ & $\mathrm{Cl}^{-}$ & $\mathrm{Ca}^{++}$ & $\mathrm{Mg}^{++}$ & $\mathbf{N a}^{+}$ & $\mathbf{K}^{+}$ \\
\hline $1^{\mathrm{st}}$ & 040 & 7.37 & 1.62 & 12.31 & - & 45.7 & 157.8 & 542.3 & 55.4 & 43.1 & 268.1 & 34.2 \\
\hline $2^{\text {nd }}$ & $0-40$ & 7.21 & 1.44 & 10.05 & - & 27.4 & 137.2 & 488.7 & 41.3 & 31.0 & 249.5 & 21.1 \\
\hline
\end{tabular}

Table (3). Chemical analysis of the irrigation water.

\begin{tabular}{ccccccccccc}
\hline \multirow{2}{*}{ Season } & $\mathbf{p H}$ & \multicolumn{3}{c}{$\mathbf{E C}$} & \multicolumn{3}{c}{ Soluble anions (ppm) } & \multicolumn{4}{c}{ Soluble cations (ppm) } \\
& & $\mathbf{d S / m}$ & $\mathbf{C O}_{3}{ }^{-}$ & $\mathbf{H C O}_{\mathbf{3}}{ }^{-}$ & $\mathbf{S o}_{\mathbf{4}}{ }^{-2}$ & $\mathbf{C l}^{-}$ & $\mathbf{C a}^{++}$ & $\mathbf{M g}^{++}$ & $\mathbf{N a}^{+}$ & $\mathbf{K}^{+}$ \\
\hline $1^{\text {st }}$ & 7.12 & 2.22 & - & 57.50 & 294.3 & 602 & 98.4 & 61.4 & 547.8 & 16.4 \\
$2^{\text {nd }}$ & 7.10 & 2.07 & - & 55.5 & 380.2 & 540.1 & 88.8 & 87.6 & 319.5 & 21.1 \\
\hline
\end{tabular}

\section{Data Recorded}

\section{Insect Observations}

Samplings of potato leaves with four replicates were arranged in a split block design. Samples of 25 leaflets from each replicate representing different levels and directions of the plants were randomly collected to investigate potato insects attacking potato plants (Sharaby et al., 2015). For all treatments, samples of infested leaves were collected immediately before spraying as index of pre-treatment count, and every 15 days after the successive sprays to determine the level of infestation. The collected samples were kept in paper bags in a refrigerator till examined by the use of a binocular microscope. They were separated, identified and counted. The percentage of reduction in infestation was calculated according to the formula (Topps and Wain, 1957).

$$
\mathrm{R} \%=\frac{\mathrm{C}-\mathrm{T}}{\mathrm{C}} \times 100
$$

Where: 
C: Number of insects recorded in the control samples.

$\mathrm{T}$ : Number of insects recorded in treatment samples.

\section{Disease Assessment}

The percentage of disease incidence and severity of early leaf blight natural infection was recorded before and after each spray date. Percentage of disease incidence (D.I) was calculated based on the following formula:

$$
\text { D.I }=\frac{\text { No. of infected plants }}{\text { Total plants }} \times 100
$$

The disease severity was recorded on 0 - 5 scale. Five infected plants were selected randomly from each plot and five leaves were selected from each selected plant for scoring the disease severity data (Table 4) (Singh, 2004). Percentage of disease severity (PDS) was calculated based on the following formula: Disease severity (\%) was calculated by using the following formula:

$$
\mathrm{PDS}=\frac{\text { Sum of all disease rating }}{\text { Total No. of leaves }- \text { Maximum grade }} \times 100
$$

Table (4). Score of disease severity of early blight of potato disease score disease severity.

\begin{tabular}{cc}
\hline Disease score & Disease severity \\
\hline 0 & No infection \\
1 & $0.1-1.0$ per cent leaf area affected \\
2 & $1.1-10.0$ per cent leaf area affected \\
3 & $10.1-25.0$ per cent leaf area affected \\
4 & $25.1-50.0$ per cent leaf area affected \\
5 & $<50.1$ per cent leaf area affected \\
\hline
\end{tabular}

\section{Plant Data Recorded}

\section{Growth Characters}

After 21 days from sowing, the $75 \%$ of potato Daimond cv. seedling emergency were recorded. Foliar treatments were takes place after 36, 51 and 66 days after sowing date. Five plants were randomly taken from each experimental plot after 45 and 75 days from tubers sowing to record growth characters i.e. plant leaves area $\left(\mathrm{cm}^{2}\right)$ using leaf area meter, fresh and dry weight (g) of plant foliage as well as, leaves area index (LAI), which was calculated using the equation as follows:

$$
\text { LAI }=\frac{\text { Plant leaves area }\left(\mathrm{cm}^{2}\right)}{\text { Foliage canopy area }\left(\mathrm{cm}^{2}\right)}
$$


Canopy area was measured in the middle of the day when the sun was in a perfect perpendicular position to the experiment location. Also, Net Assimilation Rate (NAR) was determined according to the equation described by Watson (1947) as follows:

$$
\mathrm{NAR}=\frac{\mathrm{W}_{2}-\mathrm{W}_{1}}{\mathrm{~T}_{2}-\mathrm{T}_{1}} \times \frac{\log _{\mathrm{e}} \mathrm{L}_{2}-\log _{\mathrm{e}} \mathrm{L}_{1}}{\mathrm{~L}_{2}-\mathrm{L}_{1}}
$$

Where:

$\mathrm{W}_{1}=$ Plant dry weight in the first $\mathrm{L}_{1}=$ Plant leaves area of first sample. sample.

$\mathrm{W}_{2}=$ Plant dry weight in the second $\mathrm{L}_{2}=$ Plant leaves area of second sample.

$\mathrm{T}_{1}=$ First sample time. sample.

$\mathrm{T}_{2}=$ Second sample time.

$\log _{\mathrm{e}}=$ Nature logarithm.

\section{Yield and its Components}

Potato tubers Daimond cv. were harvested after 105 days from sowing. Ten plants from each plot were randomly taken to determine yield components i.e. average of tubers number/plant, average of tuber fresh weight and yield/ plant, plot and feddan (feddan $=4200 \mathrm{~m}^{2}$ or 0.42 of hectare).

\section{Chemical Composition}

Chlorophyll contents $(\mathrm{mg} / 100 \mathrm{~g})$ of fresh leaves at 75 days from tubers sowing was calorimetrically determined as described in AOAC (1990).

\section{Experimental Design and Statistical Analysis}

Split block design with four replicates was used and statistically analyzed according to the method described by Thomas and Hills (1975). The foliar treatments were distributed in the blocks, while soil additives randomly occupied split-blocks (plots). The results of both investigated seasons were tested for homogeneity for applying combined analysis. Also the correlation and regression between some parameters were done.

\section{RESULTS}

\section{Effect of Kaolin and Diatoms Against Some Potato Pests}

\subsection{Treatments on leafminer fly Liriomyza huidobrensis (Blanchard)}

\subsubsection{Effect of foliar spraying on leafminer insect}

The data in table (5) indicated that infestation was significantly lower in the treated plants than untreated ones. The diatoms showed the superior effect at 5\% concentration on average cumulative leafminer infestations of leaves, leaflet and larvae. Kaolin (Super Nano) at 5\% 
concentration has the second potential effect after diatoms. Diatom at $(2.5 \%)$ and Super Nano (2.5\%) indicated lower effect than diatom and Super Nano $(5 \%)$.

Table (5). Effect of foliar treatments on leafminer fly Liriomyza huidobrensis of potato (Diamond cultivar).

\begin{tabular}{lcccccc}
\hline \multirow{2}{*}{ Foliar treatments } & \multicolumn{6}{c}{ Infestations } \\
\cline { 2 - 7 } & \multicolumn{2}{c}{ Leaves } & \multicolumn{2}{c}{ Leaflet } & \multicolumn{2}{c}{ Larvae } \\
\cline { 2 - 7 } & Mean & R \% & Mean & R \% & Mean & R \% \\
\hline Control & $16.6 \mathrm{a}$ & & $65.5 \mathrm{a}$ & & $32.5 \mathrm{a}$ & \\
Super Nano 2.5\% & $7.8 \mathrm{~b}$ & 53.0 & $31.0 \mathrm{~b}$ & 52.0 & $15.3 \mathrm{~b}$ & 52.9 \\
Super Nano 5\% & $5.9 \mathrm{~d}$ & 64.5 & $23.4 \mathrm{~d}$ & 64.3 & $11.3 \mathrm{~d}$ & 65.2 \\
Diatoms 2.5\% & $6.8 \mathrm{c}$ & 59.1 & $27.5 \mathrm{c}$ & 58.1 & $13.5 \mathrm{c}$ & 58.5 \\
Diatoms 5\% & $4.8 \mathrm{e}$ & 71.1 & $18.7 \mathrm{e}$ & 71.5 & $9.4 \mathrm{e}$ & 71.1 \\
\hline
\end{tabular}

$\mathrm{R} \%=$ Reduction percentage

*Means having similar letters in the same column are not statistically differed at $P \geq 0.05$.

\subsubsection{Effect of soil additives on leafminer}

As shown in table (6) the results indicated that variations among the treatments in reduction percentage and infestation levels of $L$. huidobrensis of potato plants Diamond cultivar were significantly lower in the treated potatoes with soil addition than untreated ones. The highest reduction was obtained from diatom sediments (DS) 5 ton/fed treatment followed by diatom sediments (DS) at $2.5 \mathrm{ton} / \mathrm{fed}$, kaolinite at $5 \mathrm{ton} / \mathrm{fed}$ and kaolinite at 2.5 ton/fed, respectively.

Table (6). Effect of soil additives on leafminer fly (Liriomyza huidobrensis) of potato (Diamond cultivar).

\begin{tabular}{lcccccc}
\hline \multirow{2}{*}{ Soil additives } & \multicolumn{6}{c}{ Infestations } \\
\cline { 2 - 7 } & \multicolumn{2}{c}{ Leaves } & \multicolumn{2}{c}{ Leaflet } & \multicolumn{2}{c}{ Larvae } \\
\cline { 2 - 7 } & Mean & $\mathbf{R} \%$ & Mean & R \% & Mean & R \% \\
\hline Control & $11.2 \mathrm{a}$ & & $44.3 \mathrm{a}$ & & $21.7 \mathrm{a}$ & \\
kaolinite 2.5 ton/fed & $9.8 \mathrm{~b}$ & 12.5 & $38.9 \mathrm{~b}$ & 12.2 & $19.4 \mathrm{~b}$ & 10.6 \\
kaolinite 5 ton/fed & $8.6 \mathrm{c}$ & 23.2 & $34.5 \mathrm{~b}$ & 22.1 & $17.1 \mathrm{c}$ & 21.2 \\
(DS) 2.5 ton/fed & $7.2 \mathrm{~d}$ & 35.7 & $28.7 \mathrm{c}$ & 35.2 & $14.2 \mathrm{~d}$ & 34.6 \\
(DS) 5 ton/fed & $5.1 \mathrm{e}$ & 54.5 & $19.8 \mathrm{~d}$ & 55.3 & $9.7 \mathrm{e}$ & 55.3 \\
\hline \multicolumn{2}{r}{$\%=$ Reduction percentage } & (DS) $=$ diatom sediments \\
$\quad$ *Means having similar letters in the same column are not statistically differed at \\
$P \geq 0.05$.
\end{tabular}

Egyptian J. Desert Res., 67, No. 1, 83-115 (2017) 


\subsubsection{The interaction effect of foliar spraying and soil additives on leafminer}

Data in table (7) indicate that the treatments decreased significantly the leafminer flay population on potato plants where the most effective treatment was the interaction between soil additive (DS at 5 ton/ fed $\times$ foliar treatment, diatoms at $5 \%$ ). On the other side, the lowest effective treatment was Super Nano at $(2.5 \%)$ without soil additives, kaolinite $(5$ ton/fed $)$ and DS (5 ton/fed).

Table (7). The average number of interaction effect of foliar treatments and soil additives on leafminer fly Liriomyza huidobrensis of potato (Diamond cultivar).

\begin{tabular}{|c|c|c|c|c|}
\hline Treatments & Measurements & $\begin{array}{c}\text { Leaves } \\
\text { infestations }\end{array}$ & $\begin{array}{c}\text { Leaflet } \\
\text { infestations }\end{array}$ & $\begin{array}{c}\text { Larva } \\
\text { infestations }\end{array}$ \\
\hline \multirow{5}{*}{ Control } & Control & $22.5 \mathrm{a}$ & $87.8 \mathrm{a}$ & $43.5 \mathrm{a}$ \\
\hline & Kaolinite $2.5 \mathrm{t} / \mathrm{fed}$ & $19.0 \mathrm{~b}$ & $74.8 \mathrm{~b}$ & $37.5 \mathrm{~b}$ \\
\hline & Kaolinite $5.0 \mathrm{t} / \mathrm{fed}$ & $17.3 \mathrm{c}$ & $68.3 \mathrm{c}$ & $33.5 \mathrm{c}$ \\
\hline & DS $2.5 \mathrm{t} / \mathrm{fed}$ & $14.0 \mathrm{~d}$ & $56.5 \mathrm{~d}$ & $28.0 \mathrm{~d}$ \\
\hline & DS $5.0 \mathrm{t} / \mathrm{fed}$ & $10.0 \mathrm{e}$ & $40.0 \mathrm{e}$ & $20.0 \mathrm{e}$ \\
\hline \multirow{5}{*}{$\begin{array}{l}\text { Super Nano } \\
2.5 \%\end{array}$} & Control & $10.3 \mathrm{e}$ & $41.0 \mathrm{e}$ & $19.8 \mathrm{e}$ \\
\hline & Kaolinite $2.5 \mathrm{t} / \mathrm{fed}$ & $8.8 \mathrm{f}$ & $35.8 \mathrm{f}$ & $17.8 \mathrm{e}$ \\
\hline & Kaolinite $5.0 \mathrm{t} / \mathrm{fed}$ & $8.0 \mathrm{f}$ & $32.0 \mathrm{f}$ & $15.8 \mathrm{e}$ \\
\hline & DS $2.5 \mathrm{t} / \mathrm{fed}$ & $7.0 \mathrm{fg}$ & $28.5 \mathrm{fg}$ & $14.0 \mathrm{e}$ \\
\hline & DS $5.0 \mathrm{t} / \mathrm{fed}$ & $5.0 \mathrm{~h}$ & $17.8 \mathrm{fgh}$ & $9.0 \mathrm{f}$ \\
\hline \multirow{5}{*}{$\begin{array}{l}\text { Super Nano } \\
5.0 \%\end{array}$} & Control & $7.8 \mathrm{f}$ & $30.8 \mathrm{f}$ & $14.8 \mathrm{e}$ \\
\hline & Kaolinite $2.5 \mathrm{t} / \mathrm{fed}$ & $6.8 \mathrm{~g}$ & $26.8 \mathrm{fg}$ & $13.0 \mathrm{e}$ \\
\hline & Kaolinite $5.0 \mathrm{t} / \mathrm{fed}$ & $5.8 \mathrm{gh}$ & $23.8 \mathrm{fg}$ & $12.3 \mathrm{e}$ \\
\hline & DS $2.5 \mathrm{t} / \mathrm{fed}$ & $5.0 \mathrm{~h}$ & $20.0 \mathrm{fg}$ & $9.8 \mathrm{f}$ \\
\hline & DS $5.0 \mathrm{t} / \mathrm{fed}$ & $4.0 \mathrm{hi}$ & $15.8 \mathrm{gh}$ & $6.8 \mathrm{~g}$ \\
\hline \multirow{5}{*}{ Diatoms $2.5 \%$} & Control & $9.0 \mathrm{ef}$ & $35.8 \mathrm{f}$ & $17.5 \mathrm{e}$ \\
\hline & Kaolinite $2.5 \mathrm{t} / \mathrm{fed}$ & $8.5 \mathrm{f}$ & $34.3 \mathrm{f}$ & $17.0 \mathrm{e}$ \\
\hline & Kaolinite $5.0 \mathrm{t} / \mathrm{fed}$ & $6.8 \mathrm{~g}$ & $28.0 \mathrm{fg}$ & $13.8 \mathrm{e}$ \\
\hline & DS $2.5 \mathrm{t} / \mathrm{fed}$ & $5.8 \mathrm{gh}$ & $22.8 \mathrm{fg}$ & $10.8 \mathrm{ef}$ \\
\hline & DS $5.0 \mathrm{t} / \mathrm{fed}$ & $4.0 \mathrm{hi}$ & $16.5 \mathrm{gh}$ & $8.3 \mathrm{fg}$ \\
\hline \multirow{5}{*}{ Diatoms $5.0 \%$} & Control & $6.5 \mathrm{~g}$ & $26.0 \mathrm{fg}$ & $13.0 \mathrm{e}$ \\
\hline & Kaolinite $2.5 \mathrm{t} / \mathrm{fed}$ & $5.8 \mathrm{gh}$ & $22.8 \mathrm{fg}$ & $11.5 \mathrm{ef}$ \\
\hline & Kaolinite $5.0 \mathrm{t} / \mathrm{fed}$ & $5.3 \mathrm{~h}$ & $20.3 \mathrm{fg}$ & $10.0 \mathrm{ef}$ \\
\hline & DS $2.5 \mathrm{t} / \mathrm{fed}$ & $4.0 \mathrm{hi}$ & $15.8 \mathrm{gh}$ & $8.3 \mathrm{fg}$ \\
\hline & DS $5.0 \mathrm{t} / \mathrm{fed}$ & $2.3 \mathrm{j}$ & $8.8 \mathrm{i}$ & $4.3 \mathrm{~h}$ \\
\hline
\end{tabular}

$\mathrm{DS}=$ diatoms sediments

*Means having similar letters in the same column are not statistically differed at $P \geq 0.05$. 


\subsection{Treatments on aphid (Myzus persica (Sulzer)}

\subsubsection{Effect of foliar spraying on aphid insects}

The data in the table (8) revealed that, diatom at $5 \%$ and Super Nano (kaolin) at 5\% showed significant results in controlling aphids as compared to the control treatment. The percent reduction of all treatments showed 15$65 \%$ in aphids as compared to the control treatment after spray applications.

Table (8). Effect of foliar treatments on aphid of potato (Myzus persica (sulzer) (Diamond cultivar).

\begin{tabular}{lcccccc}
\hline \multirow{2}{*}{ Foliar Treatments } & \multicolumn{6}{c}{ Infestations } \\
\cline { 2 - 7 } & \multicolumn{2}{c}{ Leaves } & \multicolumn{2}{c}{ Leaflet } & \multicolumn{2}{c}{ Larvae } \\
\cline { 2 - 7 } & Mean & R \% & Mean & R \% & Mean & R \% \\
\hline Control & $6.7 \mathrm{a}$ & & $26.0 \mathrm{a}$ & & $33.0 \mathrm{a}$ & \\
Super Nano 2.5\% & $5.2 \mathrm{c}$ & 22.4 & $22.1 \mathrm{~b}$ & 15.0 & $26.1 \mathrm{~b}$ & 20.9 \\
Super Nano 5\% & $2.8 \mathrm{~b}$ & 58.2 & $11.0 \mathrm{~d}$ & 57.7 & $14.0 \mathrm{~d}$ & 57.6 \\
Diatoms 2.5\% & $3.6 \mathrm{~d}$ & 46.3 & $14.0 \mathrm{c}$ & 46.2 & $17.8 \mathrm{c}$ & 46.1 \\
Diatoms 5\% & $2.4 \mathrm{e}$ & 64.2 & $9.7 \mathrm{e}$ & 62.7 & $11.3 \mathrm{e}$ & 65.8 \\
\hline R \%= Reduction percentage \\
*Means having similar letters in the same column are not statistically differed at \\
$P \geq 0.05$.
\end{tabular}

\subsubsection{Effect of soil additives on aphid insects}

The data presented in table (9) revealed significantly lower values in the treated plants than untreated ones. The evaluation of aphid infestation on potato plants implemented prior to natural products (diatom sediments (DS) and kaolinite) addition which resulted aphids accumulations and could be disregard the effect of the initial population on the final results across the treatments. Thus, we can conclude that the tested materials exhibited different control performances on potato aphids. The potato plants treated as soil addition with kaolinite at 2.5 ton/fed exhibited a moderate decrease of aphid population that was statistically similar to the infestation prior to the treatment. Among the natural products tested, the formulation of (DS) (5 ton/ fed) and kaolinite at 5 ton/fed. produced the greatest reduction in the leaves, leaflet and adult relived. The DS at $2.5 \mathrm{ton} / \mathrm{fed}$ and kaolinite at $2.5 \mathrm{ton} / \mathrm{fed}$ reduced the infestations in moderate effect.

\subsubsection{The interaction effect of foliar treatments and soil additives on aphid}

Data represented in table (10) indicate that the most effective treatment for reducing aphid was the interaction between soil additives \{ DS at $(5 \mathrm{ton} / \mathrm{fed}$.) $\times$ foliar treatments $\{$ Diatom at $(5 \%)$.The interaction between diatoms at $5 \%$ as foliar spraying $\times$ DS at 5 ton/ fed. as soil additives was recorded lowest infestation of leaves, leaflet and adults for aphid. 
Table (9). Effect of soil additives on aphid of potato plants Diamond cultivar.

\begin{tabular}{|c|c|c|c|c|c|c|}
\hline \multirow{3}{*}{ Foliar Treatments } & \multicolumn{6}{|c|}{ Infestations } \\
\hline & \multicolumn{2}{|c|}{ Leaves } & \multicolumn{2}{|c|}{ Leaflet } & \multicolumn{2}{|c|}{ Adult } \\
\hline & Mean & R \% & Mean & R \% & Mean & R \% \\
\hline Control & 7.4 & & 29.8 & & $36.4 \mathrm{a}$ & \\
\hline kaolinite 2.5 ton/fed & $4.4 \mathrm{a}$ & 40.5 & $17.1 \mathrm{a}$ & 42.6 & $22.0 \mathrm{~b}$ & 39.6 \\
\hline kaolinite 5 ton/fed & $3.1 \mathrm{~b}$ & 58.1 & $12.3 \mathrm{c}$ & 58.7 & $15.1 \mathrm{~d}$ & 58.5 \\
\hline (DS) $2.5 \mathrm{ton} / \mathrm{fed}$ & $3.7 \mathrm{c}$ & 50.0 & $15.3 \mathrm{~b}$ & 48.7 & $18.4 \mathrm{c}$ & 49.5 \\
\hline (DS) 5 ton/ fed & $2.1 \mathrm{~d}$ & 71.6 & $8.4 \mathrm{~d}$ & 71.8 & $10.2 \mathrm{e}$ & 72.0 \\
\hline
\end{tabular}

\section{Effect of Kaolin and Diatoms Against Early Blight Disease 2.1. Effect of foliar spraying on early blight disease}

The promising of foliar treatments for reducing both disease incidence and severity of early blight in field were applied under natural field conditions during two successive growing seasons (Fig. 1). The foliar treatments reduced significantly both disease incidence and severity when compared with control; diatoms at (5\%) had a superior effect in this respect followed by kaolin Super Nano at (5\%), kaolin Super Nano at $(2.5 \%)$ and diatoms at $2.5 \%$ respectively. Diatoms at $5 \%$ reduced disease incidence by $33 \%$ and disease severity by $45.6 \%$, while, diatoms at $2.5 \%$ had the lowest efficiency for reducing both the disease incidence and severity.

\subsection{Effect of soil additives on early blight disease}

Data in fig. (2) illustrated that, the soil additive treatments showed significant reduction of both incidence and severity of early blight as compared with control. The highest reduction was obtained from diatom sediments (DS) at 5 ton/fed treatment followed by kaolinite at $5 \mathrm{t} / \mathrm{fed}$, kaolinite at 2.5 ton/fed. and DS at 2.5 ton/ fed. DS at 5 ton/fed reduced disease incidence by $20.6 \%$ and disease severity by $10.4 \%$, while, DS at 2.5 ton/fed had the lowest efficacy in reducing both the disease incidence and severity by $1.8 \%$ and $2.8 \%$ respectively (Fig. 2 ).

\subsection{The interaction effect of foliar treatments and soil additives on early blight disease}

Data presented in table (11) indicated that the all interactions between foliar treatments and soil additives decreased significantly both disease incidence and disease severity of early blight. Also, data represented in table 
(11) indicate that the most effective treatment for suppressing disease incidence was the interaction between DS at 5 ton/fed as soil additive $\times$ diatoms or kaolin at $5 \%$ as foliar spraying. The lowest effective treatment to suppress disease incidence was DS or kaolinite at (2.5 ton/fed) as soil additive $\times$ diatoms at $(2.5 \%)$ as foliar spraying compared with other treatments and control (Table 11).

Table (10). The average number of interaction effect of foliar treatments and soil additives on aphid insects (Myzus persica (sulzer)) of potato (Diamond cultivar).

\begin{tabular}{|c|c|c|c|c|}
\hline Treatments & Measurements & $\begin{array}{c}\text { Leaves } \\
\text { infestations }\end{array}$ & $\begin{array}{c}\text { Leaflet } \\
\text { infestations }\end{array}$ & $\begin{array}{c}\text { Adult } \\
\text { infestations }\end{array}$ \\
\hline \multirow{5}{*}{ Control } & Control & $12.8 \mathrm{a}$ & $48.5 \mathrm{a}$ & $63.3 \mathrm{a}$ \\
\hline & Kaolinite $2.5 \mathrm{t} / \mathrm{fed}$ & $7.5 \mathrm{c}$ & $29.8 \mathrm{~b}$ & $37.8 \mathrm{~b}$ \\
\hline & Kaolinite $5.0 \mathrm{t} / \mathrm{fed}$ & $4.0 \mathrm{f}$ & $16.0 \mathrm{c}$ & $18.3 \mathrm{~cd}$ \\
\hline & DS $2.5 \mathrm{t} / \mathrm{fed}$ & $6.0 \mathrm{~d}$ & $24.3 \mathrm{dc}$ & $30.5 \mathrm{c}$ \\
\hline & DS $5.0 \mathrm{t} / \mathrm{fed}$ & $3.0 \mathrm{~g}$ & $12.0 \mathrm{e}$ & $15.0 \mathrm{~cd}$ \\
\hline \multirow{5}{*}{$\begin{array}{l}\text { Kaolin } \\
\text { Super Nano } \\
2.5 \%\end{array}$} & Control & $8.3 \mathrm{~b}$ & $33.5 \mathrm{~b}$ & $41.0 \mathrm{~b}$ \\
\hline & Kaolinite $2.5 \mathrm{t} / \mathrm{fed}$ & $6.0 \mathrm{~d}$ & $24.3 \mathrm{bc}$ & $30.3 \mathrm{c}$ \\
\hline & Kaolinite $5.0 \mathrm{t} / \mathrm{fed}$ & $4.5 \mathrm{f}$ & $18.8 \mathrm{c}$ & $22.8 \mathrm{~cd}$ \\
\hline & DS $2.5 \mathrm{t} / \mathrm{fed}$ & $4.5 \mathrm{f}$ & $21.8 \mathrm{bc}$ & $22.8 \mathrm{~cd}$ \\
\hline & DS $5.0 \mathrm{t} / \mathrm{fed}$ & $2.8 \mathrm{~g}$ & $12.0 \mathrm{c}$ & $13.5 \mathrm{~cd}$ \\
\hline \multirow{5}{*}{$\begin{array}{l}\text { Kaolin } \\
\text { Super Nano } \\
5.0 \%\end{array}$} & Control & $5.3 \mathrm{e}$ & $21.0 \mathrm{bc}$ & $26.0 \mathrm{c}$ \\
\hline & Kaolinite $2.5 \mathrm{t} / \mathrm{fed}$ & $3.0 \mathrm{~g}$ & $10.8 \mathrm{c}$ & $15.5 \mathrm{~cd}$ \\
\hline & Kaolinite $5.0 \mathrm{t} / \mathrm{fed}$ & $2.0 \mathrm{~h}$ & $8.0 \mathrm{~cd}$ & $9.5 \mathrm{~d}$ \\
\hline & DS $2.5 \mathrm{t} / \mathrm{fed}$ & $2.3 \mathrm{~h}$ & $10.0 \mathrm{~cd}$ & $11.3 \mathrm{~d}$ \\
\hline & DS $5.0 \mathrm{t} / \mathrm{fed}$ & $1.5 \mathrm{i}$ & $5.3 \mathrm{e}$ & $7.5 \mathrm{~d}$ \\
\hline \multirow{5}{*}{ Diatoms $2.5 \%$} & Control & $6.8 \mathrm{~d}$ & $27.5 \mathrm{~b}$ & $33.8 \mathrm{bc}$ \\
\hline & Kaolinite $2.5 \mathrm{t} / \mathrm{fed}$ & $3.3 \mathrm{~g}$ & $12.5 \mathrm{c}$ & $16.3 \mathrm{~cd}$ \\
\hline & Kaolinite $5.0 \mathrm{t} / \mathrm{fed}$ & $2.8 \mathrm{~g}$ & $10.8 \mathrm{c}$ & $13.8 \mathrm{~cd}$ \\
\hline & DS $2.5 \mathrm{t} / \mathrm{fed}$ & $3.0 \mathrm{~g}$ & $11.3 \mathrm{c}$ & $15.0 \mathrm{~cd}$ \\
\hline & DS $5.0 \mathrm{t} / \mathrm{fed}$ & $2.0 \mathrm{~h}$ & $8.0 \mathrm{~cd}$ & $10.0 \mathrm{~d}$ \\
\hline \multirow{5}{*}{ Diatoms $5.0 \%$} & Control & $4.0 \mathrm{f}$ & $18.5 \mathrm{bc}$ & $17.8 \mathrm{~cd}$ \\
\hline & Kaolinite $2.5 \mathrm{t} / \mathrm{fed}$ & $2.0 \mathrm{~h}$ & $8.0 \mathrm{~cd}$ & $10.0 \mathrm{~d}$ \\
\hline & Kaolinite $5.0 \mathrm{t} / \mathrm{fed}$ & $2.3 \mathrm{~h}$ & $8.0 \mathrm{~cd}$ & $11.0 \mathrm{~d}$ \\
\hline & DS $2.5 \mathrm{t} / \mathrm{fed}$ & 2.5 & 9.3 & 12.5 \\
\hline & DS $5.0 \mathrm{t} / \mathrm{fed}$ & 1.0 & 4.5 & 5.0 \\
\hline
\end{tabular}

DS $=$ diatoms sediments

* Means having similar letters in the same column are not statistically differed at $P \geq 0.05$. 

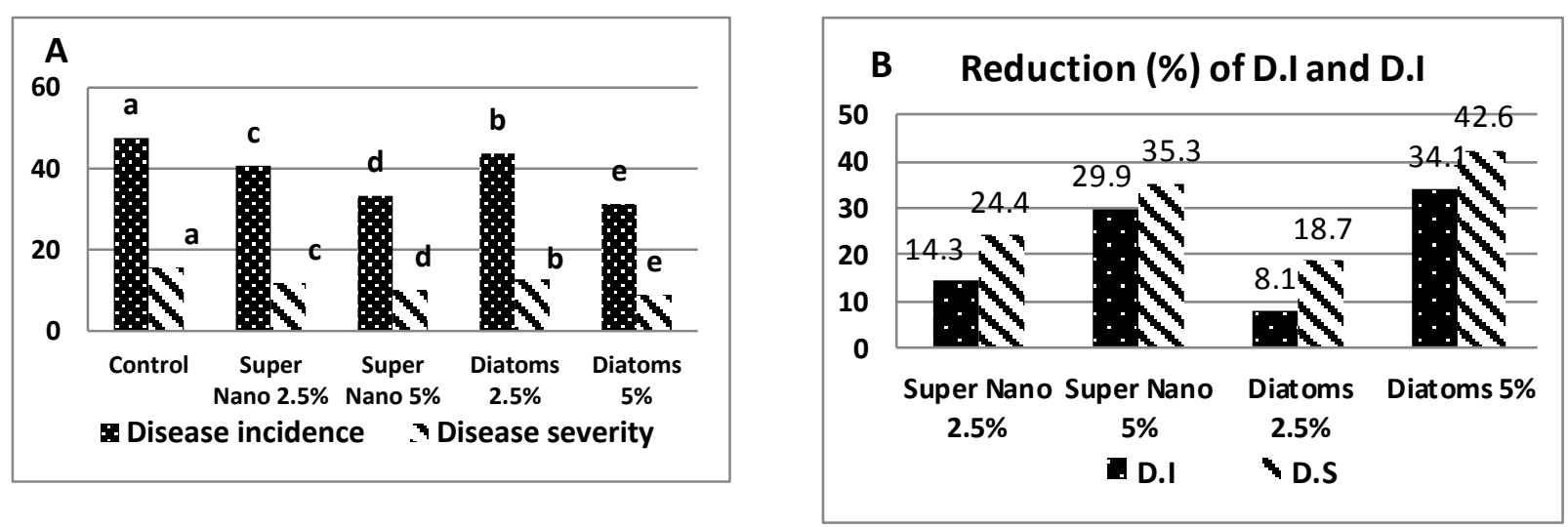

*Means having similar letters in the same column are not statistically differed at $P \geq 0.05$.

Fig (1). Effect of foliar treatments on disease incidence (D.I) and disease severity (D.S) (A) and the reduction (\%) (B) of early blight.
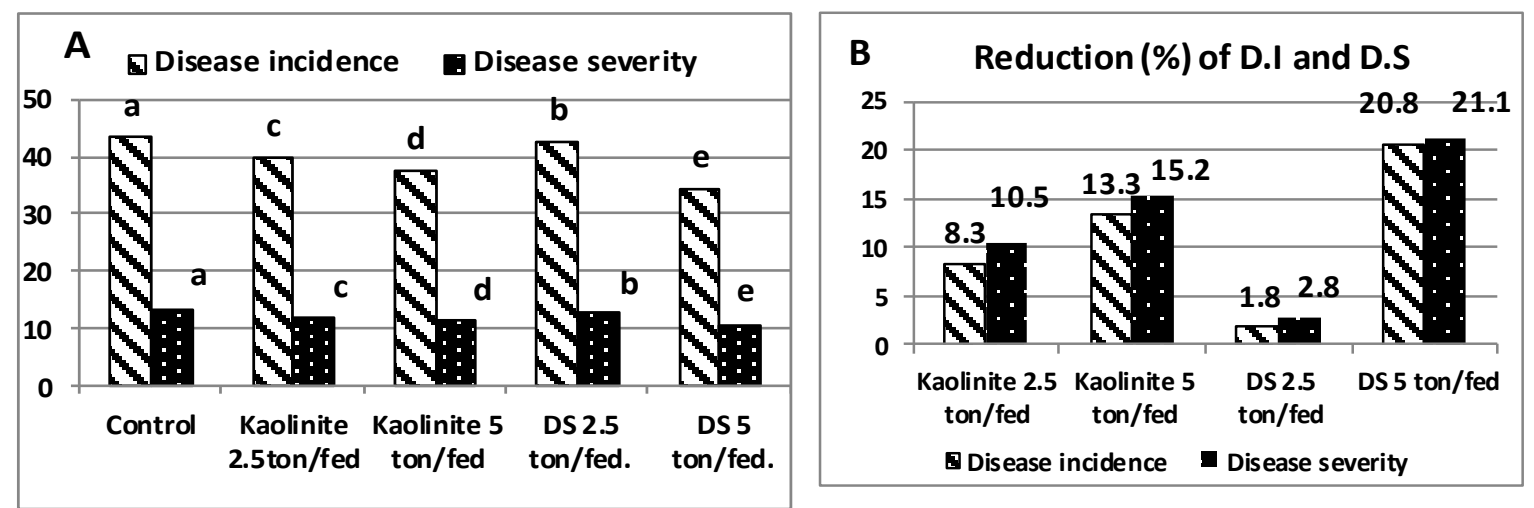

*Means having similar letters in the same column are not statistically differed at $P \geq 0.05$.

Fig (2). Effect of soil additives on disease incidence (D.I) and disease severity (D.S) (A) and the reduction (\%) (B) of early blight.

Data represented in table (11) indicate that, the most effective treatments for reducing disease severity were the interaction between kaolinite 5 ton/ fed as soil additives $\times$ diatoms at $5 \%$ as foliar spraying followed by kaolinite 2.5 ton/fed $\times$ diatoms $5 \%$, respectively. The lowest effective treatments to suppress disease severity were DS at $2.5 \mathrm{ton} / \mathrm{fed}$ as 
soil additives $\times$ diatoms at $2.5 \%$ as foliar spraying followed by DS at 2.5 ton $/$ fed $\times$ kaolin Super Nano at $2.5 \%$, respectively.

Table (11). The interaction effect of foliar treatments and soil additives on early blight disease incidence and severity.

\begin{tabular}{|c|c|c|c|}
\hline Treatments & Measurements & $\begin{array}{l}\text { Disease } \\
\text { incidence }\end{array}$ & $\begin{array}{l}\text { Disease } \\
\text { Severity }\end{array}$ \\
\hline \multirow{5}{*}{ Control } & Control & $52.2 \mathrm{a}$ & $17.2 \mathrm{a}$ \\
\hline & Kaolinite $2.5 \mathrm{t} / \mathrm{fed}$ & $47.4 \mathrm{~b}$ & $15.9 \mathrm{~b}$ \\
\hline & Kaolinite $5.0 \mathrm{t} / \mathrm{fed}$ & $45.2 \mathrm{c}$ & $14.8 \mathrm{c}$ \\
\hline & DS $2.5 \mathrm{t} / \mathrm{fed}$ & $51.4 \mathrm{ab}$ & $16.8 \mathrm{~b}$ \\
\hline & DS $5.0 \mathrm{t} / \mathrm{fed}$ & $41.7 \mathrm{e}$ & $13.8 \mathrm{~d}$ \\
\hline \multirow{5}{*}{$\begin{array}{l}\text { Kaolin Super } \\
\text { Nano } 2.5 \%\end{array}$} & Control & $43.9 \mathrm{~d}$ & $13.0 \mathrm{e}$ \\
\hline & Kaolinite $2.5 \mathrm{t} / \mathrm{fed}$ & $41.7 \mathrm{e}$ & $11.7 \mathrm{~h}$ \\
\hline & Kaolinite $5.0 \mathrm{t} / \mathrm{fed}$ & 39.9 ef & $11.2 \mathrm{i}$ \\
\hline & DS $2.5 \mathrm{t} / \mathrm{fed}$ & $42.0 \mathrm{e}$ & $12.7 \mathrm{f}$ \\
\hline & DS $5.0 \mathrm{t} / \mathrm{fed}$ & $36.4 \mathrm{fg}$ & $10.8 \mathrm{j}$ \\
\hline \multirow{5}{*}{$\begin{array}{l}\text { Kaolin Super } \\
\text { Nano } 5.0 \%\end{array}$} & Control & $37.0 \mathrm{f}$ & $10.9 \mathrm{j}$ \\
\hline & Kaolinite $2.5 \mathrm{t} / \mathrm{fed}$ & $33.1 \mathrm{~g}$ & $9.9 \mathrm{k}$ \\
\hline & Kaolinite $5.0 \mathrm{t} / \mathrm{fed}$ & $31.2 \mathrm{~h}$ & $9.8 \mathrm{k}$ \\
\hline & DS $2.5 \mathrm{t} /$ fed & $37.6 \mathrm{f}$ & $11.3 \mathrm{i}$ \\
\hline & DS $5.0 \mathrm{t} / \mathrm{fed}$ & $27.9 \mathrm{j}$ & 9.01 \\
\hline \multirow{5}{*}{ Diatoms $2.5 \%$} & Control & $47.7 \mathrm{~b}$ & $14.9 \mathrm{c}$ \\
\hline & Kaolinite $2.5 \mathrm{t} / \mathrm{fed}$ & $44.3 \mathrm{~d}$ & $12.7 \mathrm{f}$ \\
\hline & Kaolinite $5.0 \mathrm{t} / \mathrm{fed}$ & $41.2 \mathrm{ef}$ & $11.7 \mathrm{~h}$ \\
\hline & DS $2.5 \mathrm{t} / \mathrm{fed}$ & $47.4 \mathrm{e}$ & 13.7 ef \\
\hline & DS $5.0 \mathrm{t} / \mathrm{fed}$ & $38.1 \mathrm{f}$ & $10.8 \mathrm{j}$ \\
\hline \multirow{5}{*}{ Diatoms $5.0 \%$} & Control & $35.0 \mathrm{fg}$ & $10.8 \mathrm{j}$ \\
\hline & Kaolinite $2.5 \mathrm{t} / \mathrm{fed}$ & $31.3 \mathrm{~h}$ & $8.9 \mathrm{~m}$ \\
\hline & Kaolinite $5.0 \mathrm{t} / \mathrm{fed}$ & $29.7 \mathrm{i}$ & $8.5 \mathrm{~m}$ \\
\hline & DS $2.5 \mathrm{t} / \mathrm{fed}$ & $33.4 \mathrm{~g}$ & $10.1 \mathrm{jk}$ \\
\hline & DS $5.0 \mathrm{t} / \mathrm{fed}$ & $27.4 \mathrm{k}$ & $9.8 \mathrm{k}$ \\
\hline
\end{tabular}

$\mathrm{DS}=$ diatoms sediments

* Means having similar letters in the same column are not statistically differed at $P \geq 0.05$.

\section{Effect of Kaolin and Diatoms Treatments on Growth, Yield and its Component of Potato Plant \\ 3.1. Growth parameters}

The effect of the foliar spraying with concentration of kaolin and diatoms at 2.5 or $5 \%$ and soil addition with rates of kaolinite and diatom sediments (DS) at 2.5 or 5 ton/fed on growth of potato plants diamond cultivar expressed as leaves area per plant $\left(L s A \mathrm{~cm}^{2}\right)$ and leaf area index $(L A I)$ as well as foliage fresh $(F F W)$ and dry weight/plant $(F D W)$ after 45 
and 75 days from planting were presented in table (12). Results revealed that all investigated parameters were increased with sprayed diatoms at concentrations of 5 and $2.5 \%$ as compared with super Nano leaf surface film of kaolin and control treatments. Spraying with diatoms at concentrations of 2.5 and $5 \%$ significantly gradual increased the $L s A$ with 8.6 and $14.3 \%$, after 45 days, and then increased to 15.7 and $29.2 \%$ after 75 days from sowing, respectively. With the same way, the increases of $F F W$ were 3.7 and $8.2 \%$ after 45 days increased to 8.2 and 14.1 after 75 days from sowing. The $F D W$ increased by 7.3 and $15.2 \%$ after 45 days and 10.5 and $19.2 \%$ after 75 days from sowing date. Observes of spraying with super Nano of kaolin had led to sharp significant decreases with increase the concentration upon $5.0 \%$ during age plant progress. The decrement portions of $L s A, F F W$ and $F D W$ at high concentration after 75 days from sowing were 19.57, 21.64 and $28.2 \%$, respectively compared with control.

As for, the effect the soil additives of kaolinite and diatoms sediments at rate of 2.5 and 5 ton/fed of each on the late mentioned parameters, table (12) show that the investigated parameters were slights significantly increased with the tested materials as compared with the control treatment; the highest significant values were obtained, generally, with DS addition at rate of 5 ton/fed followed with DS 2.5 ton/fed., kaolinite at rate of 5 ton/fed and 2.5 ton/fed kaolinite.

Furthermore, data of the interaction among foliar treatments and soil additives presented in table (12) revealed that the highest significant values of growth parameters, were observed in plants treated with DS at rate of 5 ton/fed within blocks sprayed with diatoms at concentration of $5 \%$; followed by DS at 5 ton/fed with diatoms at $2.5 \%$; DS at 2.5 ton/fed with diatoms at 5 $\%$; kaolinite at 5 ton/fed with diatoms at $5 \%$ and kaolinite at 2.5 ton/fed with diatoms at $5 \%$.

Data in fig. (3) show the effect of foliar spraying or soil addition after 45 and 75 days from sowing on chlorophyll content. Data indicated that the concentrations 2.5 or $5.0 \%$ of kaolin as foliar spraying led to significant decrease in leaves pigments; the decrement was increased with increasing kaolin concentration and plant age.

On the other hand, foliar spray with diatoms whether 2.5 or $5 \%$ achieved the highest significant values when compared with control treatment. The increments were associated with the age progress and increase diatoms concentration.

Meanwhile, chlorophyll contents gradually increased in sequence of kaolinite at rates of 2.5 then 5 ton /fed and DS at rates of 2.5 then 5 ton/fed, respectively. The increases were retreated with increase plant age. The highest values were gotten from plants treated with 5 ton/fed of DS after 45 days from sowing date. 
Table (12). The effect of foliar treatments, soil additives and there interactions on leaves area $(L s A)$, leaf area index $(L A I)$ foliage fresh weight $(F F W)$ and foliage dry weight $(F D W)$ after 45 and 75 days from sowing of potato plants Diamond cultivar.

\begin{tabular}{|c|c|c|c|c|c|c|c|c|c|}
\hline \multirow{2}{*}{\multicolumn{2}{|c|}{ Treatments }} & \multicolumn{2}{|c|}{$L s A \mathrm{~cm}^{2} /$ plant } & \multicolumn{2}{|c|}{$\begin{array}{l}L A I \mathrm{~cm}^{2} \text { fresh } \\
\text { leaves } / \mathrm{cm}^{2} \text { soil }\end{array}$} & \multicolumn{2}{|c|}{$F F W$ g/plant } & \multicolumn{2}{|c|}{$F D W$ g/plant } \\
\hline & & $\begin{array}{c}45 \text { day } \\
\text { from } \\
\text { sowing } \\
\end{array}$ & $\begin{array}{c}75 \text { day } \\
\text { from } \\
\text { sowing } \\
\end{array}$ & $\begin{array}{c}45 \text { day } \\
\text { from } \\
\text { sowing }\end{array}$ & $\begin{array}{c}75 \text { day } \\
\text { from } \\
\text { sowing } \\
\end{array}$ & $\begin{array}{l}\mathbf{4 5} \text { day } \\
\text { from } \\
\text { sowing }\end{array}$ & $\begin{array}{c}75 \text { day } \\
\text { from } \\
\text { sowing }\end{array}$ & $\begin{array}{l}45 \text { day } \\
\text { from } \\
\text { sowing }\end{array}$ & $\begin{array}{c}75 \text { day } \\
\text { from } \\
\text { sowing }\end{array}$ \\
\hline \multicolumn{10}{|c|}{ Effect of foliar applications } \\
\hline Control & & $490 \mathrm{c}$ & $1819 \mathrm{c}$ & $1.15 \mathrm{a}$ & $2.36 \mathrm{c}$ & $75.6 \mathrm{~d}$ & $305 \mathrm{c}$ & $15.1 \mathrm{bc}$ & $61.0 \mathrm{c}$ \\
\hline Kaolin 2 & & $458 \mathrm{~d}$ & $1655 \mathrm{~d}$ & $1.12 \mathrm{a}$ & $2.15 \mathrm{~d}$ & $78.1 \mathrm{c}$ & $268 \mathrm{~d}$ & $14.4 \mathrm{~cd}$ & $50.4 \mathrm{~d}$ \\
\hline Kaolin 5 & & $447 \mathrm{e}$ & $1463 \mathrm{e}$ & $1.11 \mathrm{a}$ & $1.90 \mathrm{e}$ & $80.3 \mathrm{~b}$ & $239 \mathrm{e}$ & $14.3 \mathrm{~cd}$ & $43.8 \mathrm{e}$ \\
\hline Diatoms & $.5 \%$ & $532 \mathrm{~b}$ & $2105 \mathrm{~b}$ & $1.16 \mathrm{a}$ & $2.73 \mathrm{~b}$ & $78.4 \mathrm{c}$ & $330 \mathrm{~b}$ & $16.2 \mathrm{ab}$ & $67.4 \mathrm{~b}$ \\
\hline Diatoms & $.0 \%$ & $560 \mathrm{a}$ & $2352 \mathrm{a}$ & $1.18 \mathrm{a}$ & $3.05 \mathrm{a}$ & $81.8 \mathrm{a}$ & $348 \mathrm{a}$ & $17.4 \mathrm{a}$ & $72.7 \mathrm{a}$ \\
\hline \multicolumn{10}{|c|}{ Effect of soil applications } \\
\hline Control & & $455 \mathrm{e}$ & $1584 \mathrm{~d}$ & $1.13 \mathrm{~b}$ & $2.06 \mathrm{~d}$ & $74.6 \mathrm{~d}$ & $253 \mathrm{~d}$ & $14.2 \mathrm{~d}$ & $48.2 \mathrm{~d}$ \\
\hline Kaolinite & $2.5 \mathrm{t} / \mathrm{fed}$ & $473 \mathrm{~d}$ & $1732 \mathrm{c}$ & $1.15 \mathrm{ab}$ & $2.25 \mathrm{c}$ & $76.6 \mathrm{c}$ & $275 \mathrm{c}$ & $14.6 \mathrm{~d}$ & $52.7 \mathrm{c}$ \\
\hline Kaolinite & $5.0 \mathrm{t} / \mathrm{fed}$ & $496 \mathrm{c}$ & $1961 \mathrm{~b}$ & $1.13 \mathrm{~b}$ & $2.55 \mathrm{~b}$ & $77.9 \mathrm{c}$ & $312 b$ & $15.3 \mathrm{c}$ & $62.5 \mathrm{~b}$ \\
\hline DS $2.5 \mathrm{t} /$ & & $516 \mathrm{~b}$ & $1981 \mathrm{~b}$ & $1.15 \mathrm{ab}$ & $2.57 \mathrm{~b}$ & $80.9 \mathrm{~b}$ & $308 \mathrm{~b}$ & $16.1 \mathrm{~b}$ & $61.7 \mathrm{~b}$ \\
\hline DS $5.0 \mathrm{t} /$ & & $547 \mathrm{a}$ & $2136 \mathrm{a}$ & $1.16 \mathrm{a}$ & $2.77 \mathrm{a}$ & $84.2 \mathrm{a}$ & $342 \mathrm{a}$ & $17.1 \mathrm{a}$ & $70.0 \mathrm{a}$ \\
\hline \multicolumn{10}{|c|}{ Effect of interaction } \\
\hline \multirow{5}{*}{ Control } & Control & $445 \mathrm{ijkl}$ & $1540 \mathrm{kl}$ & $1.14 \mathrm{ab}$ & $2.001 \mathrm{~m}$ & $72.5 \mathrm{o}$ & $250 \mathrm{i}$ & 13.9 fghi & $48.1 \mathrm{jkl}$ \\
\hline & $\begin{array}{l}\text { Kaolinite } \\
2.5 \mathrm{t} / \mathrm{fed}\end{array}$ & 479ghij & $1730 \mathrm{hi}$ & $1.15 \mathrm{ab}$ & $2.25 \mathrm{hij}$ & $\begin{array}{l}74.1 \\
\text { lmno }\end{array}$ & $287 \mathrm{~h}$ & 14.4 efghi & $56.3 \mathrm{ghi}$ \\
\hline & $\begin{array}{l}\text { Kaolinite } \\
5.0 \mathrm{t} / \mathrm{fed}\end{array}$ & 507 efgh & $1914 \mathrm{fg}$ & $1.13 \mathrm{ab}$ & $2.49 \mathrm{fg}$ & $\begin{array}{l}74.4 \\
\text { jklmn }\end{array}$ & 319 ef & $15.3 \mathrm{defg}$ & $65.5 \mathrm{def}$ \\
\hline & $\begin{array}{l}\text { DS } 2.5 \\
t / \text { fed }\end{array}$ & 486 ghi & $1855 \mathrm{gh}$ & $1.16 \mathrm{ab}$ & $2.41 \mathrm{gh}$ & $\begin{array}{l}75.9 \\
\text { ijklm }\end{array}$ & $316 \mathrm{ef}$ & $15.2 \mathrm{defgh}$ & $63.0 \mathrm{efg}$ \\
\hline & $\begin{array}{l}\text { DS } 5.0 \\
\mathrm{t} / \mathrm{fed}\end{array}$ & $531 \mathrm{de}$ & $2057 \mathrm{de}$ & $1.17 \mathrm{a}$ & $2.67 \mathrm{de}$ & $81.2 \mathrm{efg}$ & $352 \mathrm{bc}$ & $16.6 \mathrm{~cd}$ & $72.1 \mathrm{bcd}$ \\
\hline \multirow{5}{*}{$\begin{array}{l}\text { Kaolin } \\
2.5 \%\end{array}$} & Control & $435 \mathrm{klm}$ & 1419im & $1.10 \mathrm{ab}$ & $1.84 \mathrm{mn}$ & $\begin{array}{l}73.7 \\
\text { mno }\end{array}$ & $225 \mathrm{jk}$ & 13.6 ghi & $41.5 \mathrm{~lm}$ \\
\hline & $\begin{array}{l}\text { Kaolinite } \\
2.5 \mathrm{t} / \text { fed }\end{array}$ & $425 \mathrm{~lm}$ & $1544 \mathrm{kl}$ & $1.13 \mathrm{ab}$ & $2.011 \mathrm{~m}$ & $\begin{array}{l}75.2 \\
\text { jklmn }\end{array}$ & $240 \mathrm{ij}$ & $13.7 \mathrm{ghi}$ & 43.71 \\
\hline & \multirow{3}{*}{$\begin{array}{l}\text { Kaolinite } \\
5.0 \text { t/fed } \\
\text { DS } 2.5 \\
\text { t/fed } \\
\text { DS } 5.0 \\
\text { t/fed }\end{array}$} & 453hijk & $1748 \mathrm{hi}$ & $1.10 \mathrm{ab}$ & 2.27hij & $78.1 \mathrm{hi}$ & $280 \mathrm{~h}$ & 14.5 efghi & $53.5 \mathrm{ijk}$ \\
\hline & & 486 ghi & $1736 \mathrm{hi}$ & $1.14 \mathrm{ab}$ & $2.26 \mathrm{hij}$ & 81.0 efg & $286 \mathrm{~h}$ & 15.2 defgh & $54.6 \mathrm{hij}$ \\
\hline & & 489fghi & $1824 \mathrm{gh}$ & $1.15 \mathrm{ab}$ & $2.37 \mathrm{ghi}$ & 82.5 cde & $307 \mathrm{fg}$ & $15.3 \mathrm{defg}$ & 58.7 fghi \\
\hline \multirow[b]{2}{*}{$\begin{array}{l}\text { Kaolin } \\
5.0 \%\end{array}$} & Control & \multirow{2}{*}{$\begin{array}{l}422 \mathrm{~lm} \\
403 \mathrm{~m}\end{array}$} & \multirow{2}{*}{$\begin{array}{l}1271 \mathrm{~m} \\
1350 \mathrm{im}\end{array}$} & $1.08 \mathrm{~b}$ & $1.65 \mathrm{no}$ & $76.9 \mathrm{ij}$ & 1961 & $13.2 \mathrm{i}$ & $34.3 \mathrm{~m}$ \\
\hline & $\begin{array}{l}\text { Kaolinite } \\
2.5 \mathrm{t} / \text { fed }\end{array}$ & & & $1.11 \mathrm{ab}$ & $1.75 \mathrm{mn}$ & $79.2 \mathrm{gh}$ & $207 \mathrm{kl}$ & $13.4 \mathrm{hi}$ & $35.7 \mathrm{~m}$ \\
\hline
\end{tabular}




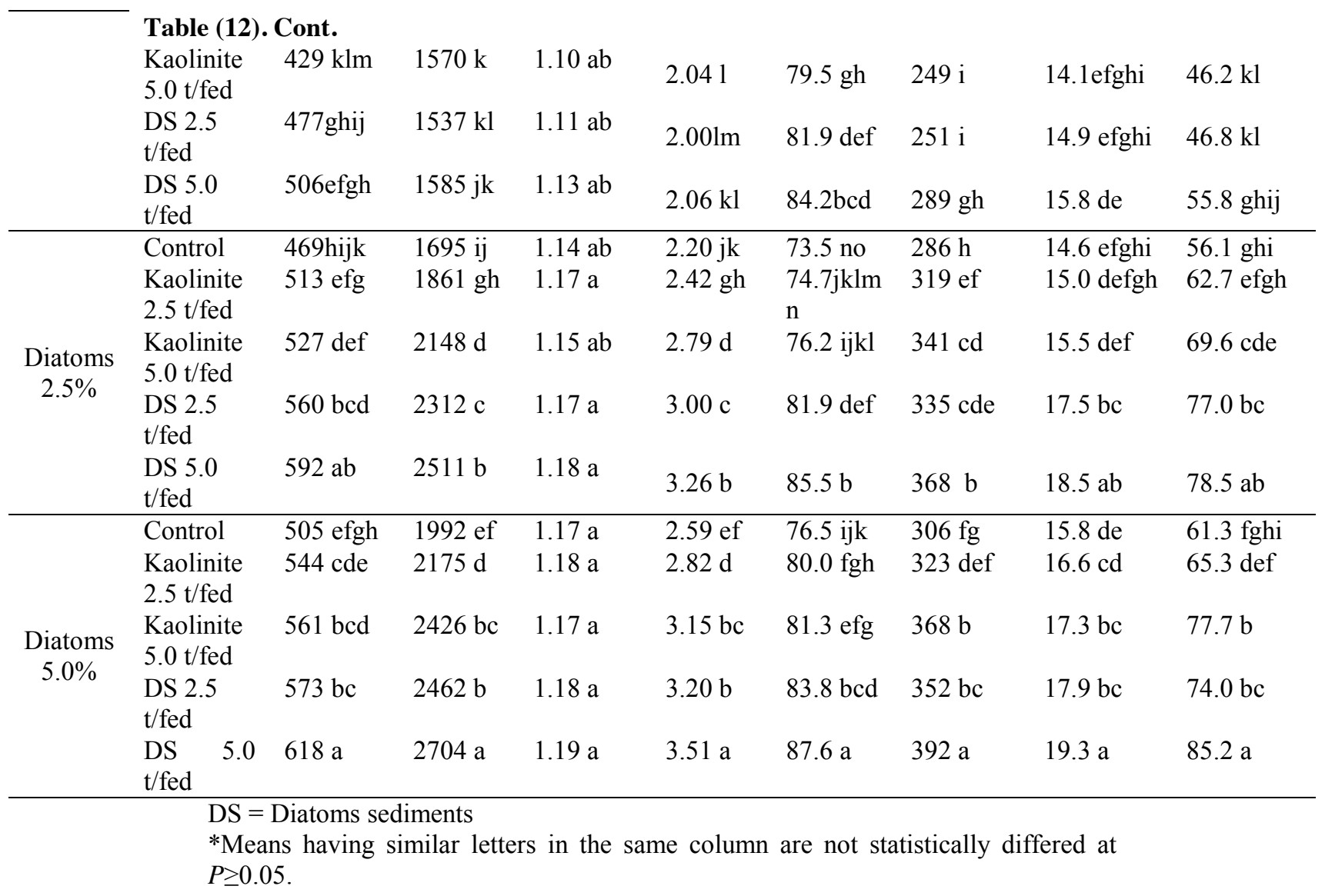

Interaction values in table (13), cleared that the significant highest pigments concentration have been achieved from plants sown since 75 days and grown in soil treated with 5 ton/ fed kaolinite within blocks sprayed with diatoms at concentration of 2.5 or $5 \%$, followed by those treated with 2.5 ton/fed kaolinite and sprayed with $5 \%$ diatoms then 2.5 ton/fed DS within diatoms $5 \%$.

Net assimilation rate as influenced by single treatments of foliar application or soil addition of kaolin and diatoms were graphed in fig. (4). Data cleared that the dry matter accumulation was significantly increased with diatoms spraying compared with kaolin concentrations. The highest values were obtained with diatoms at concentration of 2.5 and $5 \%$. While the investigated soil addition showed the superiority achievement of 5 ton/fed kaolinite and 5 ton/fed diatoms sediments.

The effect of interaction between foliar spraying and soil addition as shown in table (13), led to significant increase of dry matter accumulation in plant tissues. The highest values of dry matter being 713.6, 686.1, 685.1, $679.0,677.3$ and $673.7 \mu \mathrm{g} / \mathrm{cm}^{2} /$ day have been made from treatments of 5 
ton/fed DS, 5 ton/fed kaolinite, 5 ton/fed kaolinite within blocks sprayed with diatoms at concentration of 5\%; 5 ton/ fed kaolinite with diatoms $2.5 \%$; 2.5 ton/fed DS and 2.5 ton/fed in diatoms $5 \%$, respectively.

\section{Effect of Kaolin and Diatoms on Potato Yield and its Components}

The effect of foliar spraying and single or mixed soil addition of kaolin and diatoms on potato tuber yield and its components expressed as: average of tubers number, the average of tuber weight and tubers yield per plant, plot and feddan were illustrated in table (14). Data show that the foliar spraying with diatoms at concentrations of 5.0 and $2.5 \%$ significantly increased yield and its components compared with control or kaolin treatments. The increase portions for tubers number and tuber weight when compared with control treatment were 6.9 and $4.3 \%$, respectively. While the highest increase portions compared with the lowest values achieved of kaolin spraying at concentration of 5\% were 28.3 and $17.5 \%$ for the same let mentioned characters, respectively. While, The increment of tuber yield per plant, per plot and per feddan were 51.2, 49.1 and $49.3 \%$, respectively more than lowest yield achieved with plants sprayed with kaolin at concentration of $5 \%$ and were $11.7,10.9$ and $10.8 \%$, respectively for recently mentioned parameters more than control treatment.

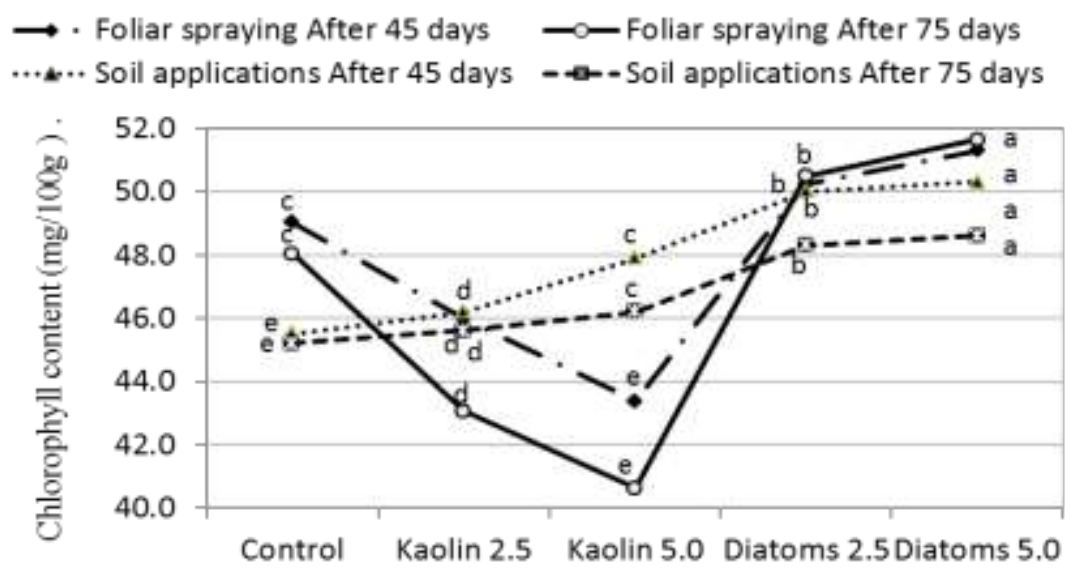

Means having similar letters in the same column are not statistically differed at $P \geq 0.05$.

Fig. (3). Single effect of foliar spraying and soil application treatments of kaolin and diatoms on chlorophyll content $(\mathrm{mg} / 100 \mathrm{~g})$ after 45 and 75 days from sowing of potato plants Diamond cultivar. 
Table (13). The effect interactions of foliar treatments and soil additives on chlorophyll content $(\mathrm{mg} / 100 \mathrm{~g})$ after 45 and 75 days from sowing and Net assimilation rate (NAR) $\mu \mathrm{g} / \mathrm{cm}^{2} /$ day of potato plants Diamond cultivar.

\begin{tabular}{|c|c|c|c|c|}
\hline \multirow{2}{*}{ Treatment } & \multirow[t]{2}{*}{ Measurements } & \multicolumn{2}{|c|}{ Chlorophyll content } & \multirow[b]{2}{*}{$\begin{array}{l}\text { NAR } \mu \mathrm{g} / \\
\mathrm{cm}^{2} / \mathrm{day}\end{array}$} \\
\hline & & $\begin{array}{l}45 \text { days } \\
\text { after } \\
\text { sowing }\end{array}$ & $\begin{array}{l}75 \text { days } \\
\text { after } \\
\text { sowing }\end{array}$ & \\
\hline \multirow{5}{*}{ Control } & Control & $47.0 \mathrm{fgh}$ & $47.2 \mathrm{~d}$ & 561.5 cdefg \\
\hline & Kaolinite $2.5 \mathrm{t} / \mathrm{fed}$ & $47.1 \mathrm{fgh}$ & $45.3 \mathrm{de}$ & $623.0 \mathrm{abc}$ \\
\hline & Kaolinite $5.0 \mathrm{t} / \mathrm{fed}$ & $47.8 \mathrm{efg}$ & $45.7 \mathrm{de}$ & $686.4 \mathrm{ab}$ \\
\hline & DS $2.5 \mathrm{t} / \mathrm{fed}$ & $51.6 \mathrm{ab}$ & $50.9 \mathrm{abc}$ & $677.3 \mathrm{abc}$ \\
\hline & DS $5.0 \mathrm{t} / \mathrm{fed}$ & $51.7 \mathrm{ab}$ & $51.1 \mathrm{abc}$ & $713.7 \mathrm{a}$ \\
\hline \multirow{5}{*}{$\begin{array}{c}\text { Kaolin } \\
2.5 \%\end{array}$} & Control & $43.1 \mathrm{jk}$ & $39.9 \mathrm{fg}$ & $484.5 \mathrm{hi}$ \\
\hline & Kaolinite $2.5 \mathrm{t} / \mathrm{fed}$ & $43.9 \mathrm{ijk}$ & $41.4 \mathrm{f}$ & 500.6 fghi \\
\hline & Kaolinite $5.0 \mathrm{t} / \mathrm{fed}$ & $44.9 \mathrm{hij}$ & $40.7 \mathrm{fg}$ & 588.8 bcdef \\
\hline & DS $2.5 \mathrm{t} / \mathrm{fed}$ & 48.4 defg & $46.0 \mathrm{de}$ & 581.3 cdefg \\
\hline & DS $5.0 \mathrm{t} / \mathrm{fed}$ & 49.7 bcde & $47.3 \mathrm{~d}$ & $619.2 \mathrm{abcd}$ \\
\hline \multirow{5}{*}{$\begin{array}{c}\text { Kaolin } \\
5.0 \%\end{array}$} & Control & 40.61 & $37.4 \mathrm{~h}$ & $397.3 \mathrm{j}$ \\
\hline & Kaolinite $2.5 \mathrm{t} / \mathrm{fed}$ & $41.8 \mathrm{kl}$ & $39.2 \mathrm{fgh}$ & $411.7 \mathrm{ij}$ \\
\hline & Kaolinite $5.0 \mathrm{t} / \mathrm{fed}$ & $43.0 \mathrm{jk}$ & $38.4 \mathrm{gh}$ & 527.4 defgh \\
\hline & DS $2.5 \mathrm{t} / \mathrm{fed}$ & $45.3 \mathrm{hij}$ & $43.6 \mathrm{e}$ & 509.8 efgh \\
\hline & DS $5.0 \mathrm{t} / \mathrm{fed}$ & $46.1 \mathrm{ghi}$ & $44.5 \mathrm{e}$ & $609.5 \mathrm{bcd}$ \\
\hline \multirow{5}{*}{$\begin{array}{c}\text { Diatoms } \\
2.5 \%\end{array}$} & Control & $47.8 \mathrm{efg}$ & $49.7 \mathrm{c}$ & $627.8 \mathrm{abc}$ \\
\hline & Kaolinite $2.5 \mathrm{t} / \mathrm{fed}$ & $47.9 \mathrm{efg}$ & $50.3 \mathrm{bc}$ & $659.5 \mathrm{abc}$ \\
\hline & Kaolinite $5.0 \mathrm{t} / \mathrm{fed}$ & $51.5 \mathrm{abc}$ & $53.4 \mathrm{a}$ & $679.0 \mathrm{abc}$ \\
\hline & DS $2.5 \mathrm{t} / \mathrm{fed}$ & $52.1 \mathrm{ab}$ & $49.7 \mathrm{c}$ & $618.1 \mathrm{abcd}$ \\
\hline & DS $5.0 \mathrm{t} / \mathrm{fed}$ & $51.9 \mathrm{ab}$ & $49.5 \mathrm{c}$ & $654.0 \mathrm{abc}$ \\
\hline \multirow{5}{*}{$\begin{array}{c}\text { Diatoms } \\
5.0 \%\end{array}$} & Control & $49.2 \mathrm{cdef}$ & $51.7 \mathrm{abc}$ & $607.0 \mathrm{bcd}$ \\
\hline & Kaolinite $2.5 \mathrm{t} / \mathrm{fed}$ & $50.4 \mathrm{abcd}$ & $51.9 \mathrm{abc}$ & 596.8 bcde \\
\hline & Kaolinite 5.0 t/fed & $52.0 \mathrm{ab}$ & $52.7 \mathrm{ab}$ & $685.1 \mathrm{ab}$ \\
\hline & DS $2.5 \mathrm{t} / \mathrm{fed}$ & $52.9 \mathrm{a}$ & $51.4 \mathrm{abc}$ & $626.5 \mathrm{abc}$ \\
\hline & DS $5.0 \mathrm{t} / \mathrm{fed}$ & $52.0 \mathrm{bc}$ & $50.5 \mathrm{bc}$ & $673.7 \mathrm{abc}$ \\
\hline
\end{tabular}

$\mathrm{DS}=$ Diatoms sediments

* Means having similar letters in the same column are not statistically differed at $P \geq 0.05$. 


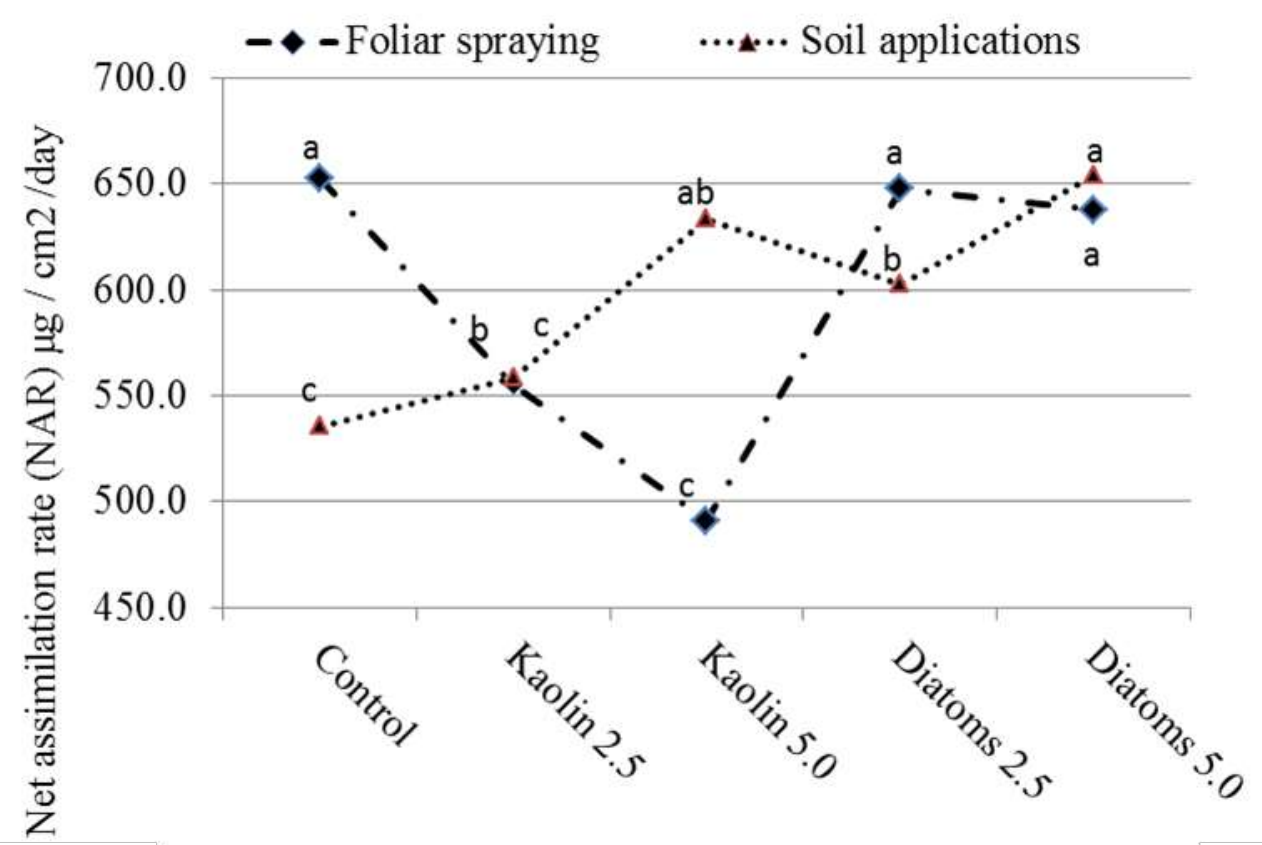

Means having similar letters in the same column are not statistically differed at $P \geq 0.05$.

Fig. (4). Single effect of foliar spraying and soil application treatments of kaolin and diatoms on net assimilation rate (NAR; $\mu \mathrm{g} / \mathrm{cm}^{2} /$ day) of potato Diamond cultivar.

Also, data in table (14) cleared that a significant slight increases in tubers number per plant, tuber weight and tubers yield per plant, plot and feddan as reaction of soil additive treatments when compared with control. Nevertheless, the highest values of tuber weight have gotten in plants treated with DS at rate of 2.5 ton per feddan. The highest increase portion was 10.2 more than control. The highest yield quantities were achieved from plants grown in soil treated with 5 ton per feddan of diatom sediments as compared with untreated plants. The increments were 18.7, 17.6 and $17.9 \%$ of tubers yield per plant, tubers yield per plot and tubers yield per feddan, respectively.

According to the effect of the interaction between foliar treatments kaolin and diatoms at concentration of 2.5 and $5 \%$ and control treatment, also soil additive treatments (kaolinite and diatoms sediments at rate of 2.5 and 5 ton per feddan and control) on recently mentioned parameters, data tabulated in table (14) in generally, show that highest significant values in all measured parameters of plants sprayed with both diatoms concentrations and 
grown in soil treated with DS at rate of 5 or 2.5 ton per feddan or kaolinite at rate of 5 ton per feddan. The gotten increments were more than the increases achieved of separate foliar spray or soil additive treatments.

Table (14). Effect of foliar treatments and soil additives on average of tubers number/plant, average of tuber fresh weight $(\mathrm{g})$ and tuber yield per plant, plot and feddan of potato plants Diamond cultivar.

\begin{tabular}{|c|c|c|c|c|c|c|}
\hline \multicolumn{2}{|c|}{ Treatments } & $\begin{array}{c}\text { Tubers } \\
\text { number } \\
\text { / plant }\end{array}$ & $\begin{array}{c}\text { Tuber } \\
\text { fresh } \\
\text { weight } \\
(\mathrm{g})\end{array}$ & $\begin{array}{c}\text { Tuber } \\
\text { yield }(\mathrm{g}) / \\
\text { plant }\end{array}$ & $\begin{array}{c}\text { Tuber } \\
\text { yield } \\
(\mathbf{k g}) / \\
\text { plot }\end{array}$ & $\begin{array}{c}\text { Tuber } \\
\text { yield } t / \text { fed }\end{array}$ \\
\hline \multicolumn{7}{|c|}{ Effect of foliar applications } \\
\hline \multicolumn{2}{|l|}{ Control } & $7.2 \mathrm{~b}$ & $116 \mathrm{~b}$ & $830.6 \mathrm{c}$ & $40.5 \mathrm{c}$ & $16.21 \mathrm{c}$ \\
\hline \multicolumn{2}{|c|}{ Kaolin $2.5 \%$} & $6.6 \mathrm{c}$ & $109 \mathrm{c}$ & $715.0 \mathrm{~d}$ & $35.1 \mathrm{~d}$ & $14.03 \mathrm{~d}$ \\
\hline \multicolumn{2}{|c|}{ Kaolin $5.0 \%$} & $6.0 \mathrm{~d}$ & $103 \mathrm{~d}$ & $613.4 \mathrm{e}$ & $30.1 \mathrm{e}$ & $12.03 \mathrm{e}$ \\
\hline \multicolumn{2}{|c|}{ Diatoms $2.5 \%$} & $7.4 \mathrm{ab}$ & $119 \mathrm{ab}$ & $882.3 \mathrm{~b}$ & $42.9 \mathrm{~b}$ & $17.16 \mathrm{~b}$ \\
\hline \multicolumn{2}{|c|}{ Diatoms $5.0 \%$} & $7.7 \mathrm{a}$ & $121 \mathrm{a}$ & $927.4 \mathrm{a}$ & $44.9 \mathrm{a}$ & $17.96 \mathrm{a}$ \\
\hline \multicolumn{7}{|c|}{ Effect of soil applications } \\
\hline \multicolumn{2}{|c|}{ Control } & $6.6 \mathrm{~b}$ & $108 \mathrm{c}$ & $718.4 \mathrm{bc}$ & $35.2 \mathrm{~d}$ & $14.06 \mathrm{~d}$ \\
\hline \multicolumn{2}{|c|}{ Kaolinite $2.5 \mathrm{t} / \mathrm{fed}$} & $6.9 \mathrm{ab}$ & $109 \mathrm{c}$ & $757.1 \mathrm{~b}$ & $37.0 \mathrm{c}$ & $14.79 \mathrm{c}$ \\
\hline \multicolumn{2}{|c|}{ Kaolinite $5.0 \mathrm{t} / \mathrm{fed}$} & $7.1 \mathrm{a}$ & $113 \mathrm{bc}$ & $804.2 \mathrm{ab}$ & $39.1 \mathrm{~b}$ & $15.65 \mathrm{~b}$ \\
\hline \multicolumn{2}{|c|}{ DS $2.5 \mathrm{t} / \mathrm{fed}$} & $7.0 \mathrm{a}$ & $118 \mathrm{ab}$ & 836.6 a & $40.8 \mathrm{a}$ & $16.31 \mathrm{a}$ \\
\hline \multicolumn{2}{|c|}{ DS $5.0 \mathrm{t} / \mathrm{fed}$} & $7.1 \mathrm{a}$ & $119 \mathrm{a}$ & $852.4 \mathrm{a}$ & $41.4 \mathrm{a}$ & $16.57 \mathrm{a}$ \\
\hline \multicolumn{7}{|c|}{ Effect of interaction } \\
\hline \multirow{5}{*}{ Control } & Control & 6.8 defg & $111 \mathrm{fgh}$ & $754.6 \mathrm{fg}$ & $37.2 \mathrm{de}$ & $14.89 \mathrm{de}$ \\
\hline & $\begin{array}{l}\text { Kaolinite } 2.5 \\
\mathrm{t} / \text { fed }\end{array}$ & $7.1 \mathrm{cdef}$ & $111 \mathrm{fgh}$ & 794.0 ef & $38.9 \mathrm{~d}$ & $15.54 \mathrm{~d}$ \\
\hline & $\begin{array}{l}\text { Kaolinite } 5.0 \\
\text { t/fed }\end{array}$ & $7.3 \mathrm{abcd}$ & 113 efg & 825.4 de & $39.9 \mathrm{~cd}$ & $15.98 \mathrm{~cd}$ \\
\hline & DS $2.5 \mathrm{t} / \mathrm{fed}$ & 7.2 bcde & $122 \mathrm{ab}$ & $880.4 \mathrm{c}$ & $43.1 \mathrm{bc}$ & $17.22 \mathrm{bc}$ \\
\hline & DS $5.0 \mathrm{t} / \mathrm{fed}$ & $7.4 \mathrm{abcd}$ & $122 \mathrm{ab}$ & $898.7 \mathrm{bc}$ & $43.5 \mathrm{ab}$ & $17.41 \mathrm{ab}$ \\
\hline \multirow{5}{*}{$\begin{array}{c}\text { Kaolin } \\
2.5 \%\end{array}$} & Control & $6.2 \mathrm{ijk}$ & $102 \mathrm{jk}$ & $635.6 \mathrm{ij}$ & $31.1 \mathrm{gh}$ & $12.45 \mathrm{gh}$ \\
\hline & $\begin{array}{l}\text { Kaolinite } 2.5 \\
\text { t/fed }\end{array}$ & 6.6 fghi & $104 \mathrm{ijk}$ & $679.1 \mathrm{hi}$ & $33.3 \mathrm{fg}$ & $13.33 \mathrm{fg}$ \\
\hline & $\begin{array}{l}\text { Kaolinite } 5.0 \\
\text { t/fed }\end{array}$ & $6.7 \mathrm{efgh}$ & 106 hij & $711.5 \mathrm{gh}$ & $34.8 \mathrm{ef}$ & $13.91 \mathrm{ef}$ \\
\hline & DS $2.5 \mathrm{t} / \mathrm{fed}$ & $6.6 \mathrm{efgh}$ & $114 \mathrm{defg}$ & $757.5 \mathrm{fg}$ & $37.3 \mathrm{de}$ & $14.94 \mathrm{de}$ \\
\hline & DS $5.0 \mathrm{t} / \mathrm{fed}$ & 6.7 efgh & 117 bcde & $791.4 \mathrm{ef}$ & $38.7 \mathrm{~d}$ & $15.50 \mathrm{~d}$ \\
\hline \multirow[b]{2}{*}{$\begin{array}{c}\text { Kaolin } \\
5.0 \%\end{array}$} & Control & $5.7 \mathrm{k}$ & $96 \mathrm{k}$ & $544.2 \mathrm{k}$ & $26.6 \mathrm{i}$ & $10.62 \mathrm{i}$ \\
\hline & $\begin{array}{l}\text { Kaolinite } 2.5 \\
\text { t/fed }\end{array}$ & $6.0 \mathrm{jk}$ & $99 \mathrm{kl}$ & $589.1 \mathrm{jk}$ & $28.8 \mathrm{hi}$ & $11.53 \mathrm{hi}$ \\
\hline
\end{tabular}




\begin{tabular}{|c|c|c|c|c|c|c|}
\hline & $\begin{array}{l}\text { Table (14). Cont. } \\
\text { Kaolinite } 5.0 \\
\text { t/fed }\end{array}$ & $6.2 \mathrm{ijk}$ & $102 \mathrm{jk}$ & $625.2 \mathrm{ij}$ & $30.7 \mathrm{gh}$ & $12.30 \mathrm{gh}$ \\
\hline & DS $2.5 \mathrm{t} / \mathrm{fed}$ & $6.0 \mathrm{jk}$ & 107 hij & $645.4 \mathrm{i}$ & $31.5 \mathrm{gh}$ & $12.61 \mathrm{gh}$ \\
\hline & DS $5.0 \mathrm{t} / \mathrm{fed}$ & $6.1 \mathrm{ijk}$ & 109 ghi & $663.3 \mathrm{hi}$ & $32.6 \mathrm{fg}$ & $13.06 \mathrm{fg}$ \\
\hline \multirow{5}{*}{$\begin{array}{l}\text { Diatoms } \\
2.5 \%\end{array}$} & Control & $6.9 \mathrm{defg}$ & 113 efg & 781.1 ef & $38.3 \mathrm{~d}$ & $15.32 \mathrm{~d}$ \\
\hline & $\begin{array}{l}\text { Kaolinite } 2.5 \\
\text { t/fed }\end{array}$ & $7.3 \mathrm{abcd}$ & 113 efg & $826.4 \mathrm{de}$ & $40.2 \mathrm{~cd}$ & $16.09 \mathrm{~cd}$ \\
\hline & $\begin{array}{l}\text { Kaolinite } 5.0 \\
\mathrm{t} / \text { fed }\end{array}$ & $7.6 \mathrm{abc}$ & $122 a b c$ & $922.0 \mathrm{abc}$ & $44.7 \mathrm{ab}$ & $17.90 \mathrm{ab}$ \\
\hline & DS $2.5 \mathrm{t} / \mathrm{fed}$ & $7.6 \mathrm{abc}$ & $123 a b$ & $936.2 \mathrm{ab}$ & $45.5 \mathrm{ab}$ & $18.20 \mathrm{ab}$ \\
\hline & DS $5.0 \mathrm{t} / \mathrm{fed}$ & $7.7 \mathrm{ab}$ & $123 \mathrm{ab}$ & $945.6 \mathrm{ab}$ & $45.8 \mathrm{ab}$ & $18.30 \mathrm{ab}$ \\
\hline \multirow{5}{*}{$\begin{array}{l}\text { Diatoms } \\
5.0 \%\end{array}$} & Control & $7.5 \mathrm{abc}$ & $116 \mathrm{cdef}$ & $876.5 \mathrm{~cd}$ & $42.6 \mathrm{bc}$ & $17.03 \mathrm{bc}$ \\
\hline & $\begin{array}{l}\text { Kaolinite } 2.5 \\
\text { t/fed }\end{array}$ & $7.5 \mathrm{abc}$ & $119 \mathrm{abcd}$ & $897.0 \mathrm{bc}$ & $43.6 \mathrm{ab}$ & $17.44 \mathrm{ab}$ \\
\hline & $\begin{array}{l}\text { Kaolinite } 5.0 \\
\text { t/fed }\end{array}$ & $7.6 \mathrm{abc}$ & $123 \mathrm{ab}$ & $937.0 \mathrm{ab}$ & $45.4 \mathrm{ab}$ & $18.15 \mathrm{ab}$ \\
\hline & DS $2.5 \mathrm{t} / \mathrm{fed}$ & $7.7 \mathrm{ab}$ & $125 \mathrm{a}$ & $963.7 \mathrm{a}$ & $46.5 \mathrm{a}$ & $18.61 \mathrm{a}$ \\
\hline & DS $5.0 \mathrm{t} / \mathrm{fed}$ & $7.9 \mathrm{a}$ & $123 \mathrm{ab}$ & $963.1 \mathrm{a}$ & $46.4 \mathrm{a}$ & $18.56 \mathrm{a}$ \\
\hline
\end{tabular}

\section{Correlation and Regression Tests}

Generally, the correlation and regression tests are used to reflect the relationships between dependent and independent variables, the question, what is the affecting range of potato yield with these morphological characters?

The observations from fig. (5) that potato tuber yield (ton/fed.) was significantly correlated positively with leaves area $\left(\mathrm{cm}^{2} /\right.$ plant) after 45 and 75 days from sowing. Corresponding liner coefficients of determination $\left(\mathrm{r}^{2}\right)$ were 0.77 and 0.85 , respectively, which indicated that 77.13 and $85.26 \%$, respectively of the variation in potato tuber yield per fed were related to the correlated parameters. Furthermore, the regression coefficients were 0.04 and 0.006 , respectively. This indicated that for each increase of one $\mathrm{cm}^{2}$ of leaf area after 45 and 75 days from sowing, the potato tubers yield increased by 0.04 and 0.006 ton/fed, respectively.

The accumulation of dry matter in the plant, with the same recently mentioned method in the results interpretation, fig. (6) indicated that net assimilated rate $\left(\mu \mathrm{g} / \mathrm{cm}^{2} /\right.$ day $)$, number of tubers / plant and average of tuber weight $(\mathrm{g})$ correlated with dependent potato tuber yield by $72.6,95.7$ and $94.4 \%$, respectively. Also, that accumulate one $\mu \mathrm{g} / \mathrm{cm}^{2} /$ day of dry matter in plant tissue increase the potato tuber yield with $24.6 \mathrm{~kg} / \mathrm{fed}$, while increase 
one tuber / plant or one gram in potato tuber increased potato tubers yield by 3.64 or 0.28 ton/fed of potato tuber yield.
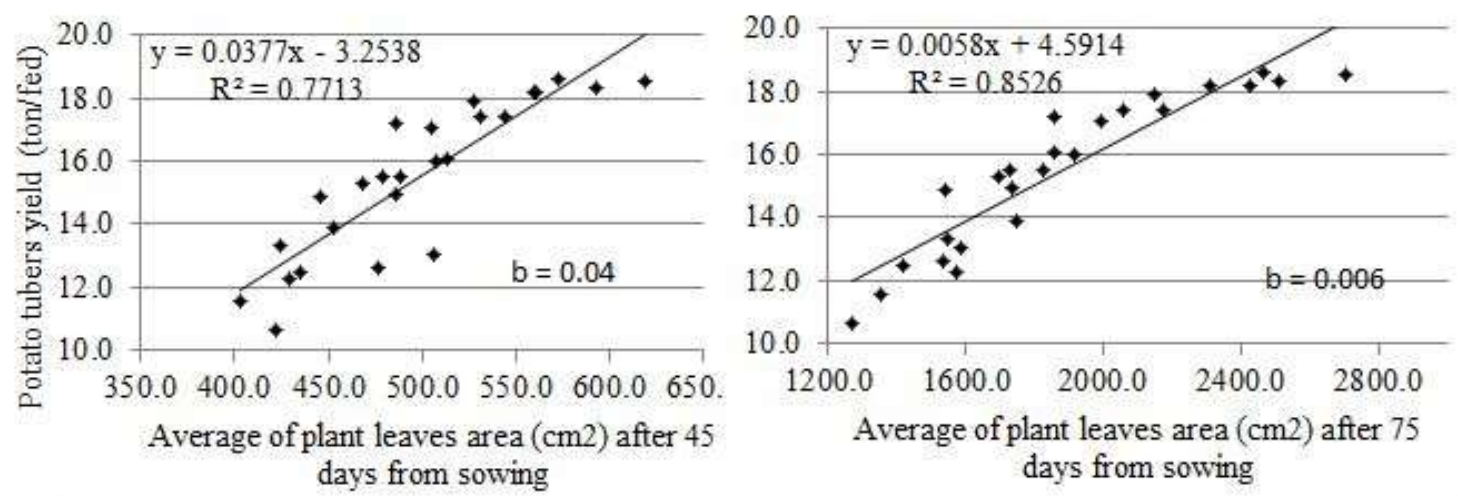

Fig. (5). Coefficient of determination $\left(r^{2}\right)$ and regression coefficients $(b)$ of potato tuber yield (ton/fed) on some independent growth variables.
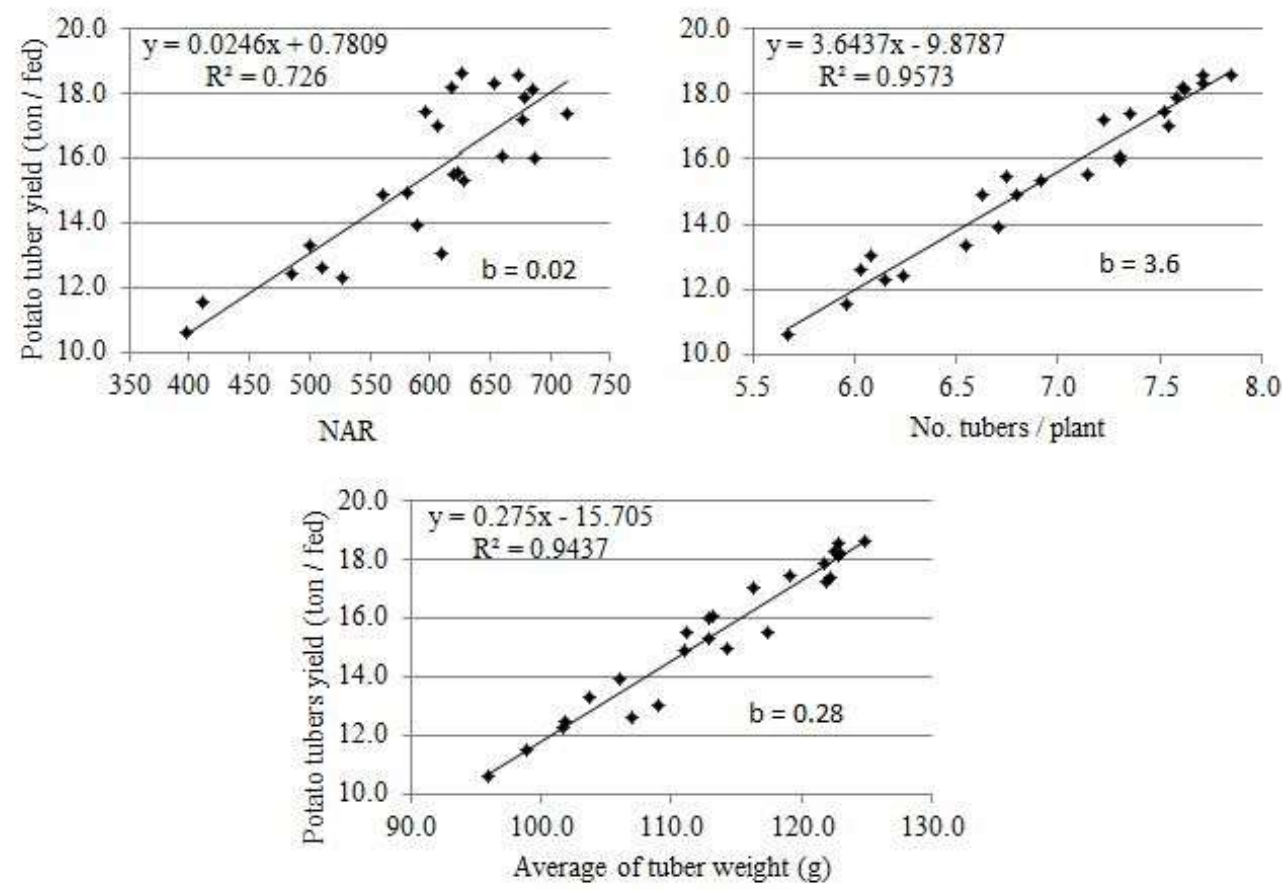

Fig. (6). Coefficient of determination $\left(\mathrm{r}^{2}\right)$ and regression coefficients (b) of potato tuber yield (ton/fed) on NAR $\left(\mu \mathrm{g} / \mathrm{cm}^{2} /\right.$ day), tuber number/plant and tuber weight $(\mathrm{g})$ independent variables. 


\section{DISCUSSION}

Natural products have played a direct role in controlling insects, and plant pathogens in the field, or indirectly through leading up to development of modern pesticides through chemical syntheses (Koivunen et al., 2013). The data proved that, foliar treatments of diatoms and kaolin (Super Nano) significantly reduced the infection levels of leafminer and aphid on potato plants as compared with untreated plants. These results were in agreement with those obtained by Markó et al. (2008), who mentioned that kaolin treatment reduced the population density of Aphis pomi, Anthonomus pomorum, and Empoasca vitis, and the number of communal caterpillar webs. The results points to the feasibility of using diatoms $5 \%$ and particle film technology (kaoline 5\%) composed of a non-toxic material, to leafminer and aphid damage as an alternative to the applications of insecticide in organic orchards. This data were at the same line with Eileen and Sydney (2016), who reported that diatoms may control soft-bodied insects like aphids, as well as slugs, millipedes and sow bugs by absorbing the waxy layer on insect bodies, abrades the skin, and dries out the insect. Diatoms 5\% and kaolin 5\% had moderate to high effects on leafminer and aphid insects with reduction percentage when compared with lower concentration.

Kaolin is a white, non-abrasive, inert aluminosilicate mineral which serve to reduce insect pest populations by repellency, disruption of feeding and oviposition (Unruh et al., 2000). Kaolin is sprayed onto plants as a liquid suspension while water evaporates leaving kaolin as a white porous protective powdery film on the leaves surface. Highly reflective white kaolin-based particle film caused a reduction of adult population. Although it is not directly toxic to insects, its insecticidal properties are repellent nature, antiovipositional qualities or due to its highly reflective white coating (Ali, 2016). Diatoms has a different mode of action than kaolin effect on insect exoskeleton, where diatoms absorbs and removes the protective waxy covering of insects that are exposed to it due to diatoms is powdered remains of fossilized diatoms and has extremely small but sharp protrusions that severely injure insects when they crawl over it (Sarwar, 2016). This covering protects insects from water loss so they dehydrate when the protective layer is removed (Sarwar, 2016). When foliar and soil treatments were used on the same potato plants, the data reveled that diatoms $5 \%$ and kaolin $5 \%$ achieved reduction of infection levels of leafminer and aphid with 25-76\% with low effect when compared with foliar spraying only. The data presented here agree with those revealed by Vincent et al. (2003), who found that kaolin is effective against spirea aphids, Aphis spiraecola, lost footing and fell off the treated plant, and damage by the potato leafhopper, Empoasca fabae, was significantly reduced.

Diatoms at $5 \%$ or kaolin at $5 \%$ as foliar spraying or/and diatom sediments (DS) 5 ton/ fed or kaolinite 5 ton/fed as soil addition had a 
superior effect to reduce significantly both disease incidence and severity of early blight disease compared with control. Foliar spraying of clays, such as kaolin as spraying or dusts have been suggested as a method of reducing fungal diseases by interfering with the ability of the pathogen to penetrate the leaf surface. Foliar spraying of kaolin as compared to current standard chemical sprays for control of downy mildew of European cucumber in commercial greenhouses. Foliar spraying of clay reduced disease severity of powdery mildew on field grown squash in Israel (Marco et al., 1994) and greenhouse cucumber (Ehret et al., 2001). Diatoms were investigated to pest management, it is very rich in silica (85\%) (Laing et al., 2006). Silicon is as an agronomic all beneficial eliminate as it confers rigidity and strength, resistance against pests and diseases (Vasanthi et al., 2014), improves water economy by reducing transportation rate, alleviates the ill effects of abiotic stresses and enhances crop yield (Vasanthi et al., 2014). Silicon nutrition suppressed the leaf blast, brown spot; sheath blight and leaf scald infection in rice (Datnoff and Rodrigues, 2005). Silicon application as calcium silicate reduced powdery mildew in cucumber (Menzies et al., 1991) and in pumpkin (Torlon et al., 2016). The accumulation of silica induces resistance by (1) playing a mechanical role as a barrier for the invading pathogen either by reducing the rate of progress of the disease or by restricting the lesion size and production of spores for secondary infection (Seebold et al., 2001) (2) by inducing host resistance by enhancing the levels of preformed inhibitors like phenolics or by mediating the synthesis of pest infectionally formed antifungal phytoalexins or by activating oxidative enzymes (Fauteux et al., 2005).

Kaolin spraying at concentration of 2.5 and $5 \%$ in earlier potato plant age, after 45 days from sowing led to increase foliage fresh weight (FFW) despite significantly decrease in the rest of vegetative measurements such as leaves number, leaves area and canopy area per plant. These increments in FFW may be due to, sprayed kaolin made antitranspiration particle film on plant leaves led to increase free water in plant tissues, in turn increase plant fresh weight. This result agreement with those obtained by Glenn et al. (2010), who found that kaolin spray increased leaf water potential and lowered stomatal conductance, also Javan et al. (2013) indicated that spraying kaolin at concentration of $6 \%$ decreased node number, stem height and diameter of soybean plants. Support this hypothesis that dry foliage weight, chlorophyll content accumulated dry weight in plant tissue were decreased significantly in the same sample. This agree with the finding by Steiman and Bittenbender (2007), who mentioned that kaolin spraying reduced photosynthetically active radiation and ultraviolet transmission. The leafminer and aphid as well as early blight which destroy leaves mesophyll tissue, sucking the plant cells juices or complete defoliation of plants, especially in young and soft parts in turn decrease plant fresh weight or 
death whole plant, were significantly decreased with using kaolin as particulate film on potato leaves.

This finding may be due to kaolin physical properties especially the white color and small particulate size that accumulate on plant leaves surface led to close the stomata and reflect sun light in turn reduce gas exchangeable between the plant and the atmosphere so, reduce photosynthetic process which in turn reduce the biological appearance. This hypothesis is in agreement with finding reported by Glenn et al. (2010), Steiman and Bittenbender (2007) and Javan et al. (2013).

The spraying treatments of diatoms at concentrations of 2.5 and $5 \%$ through different plant phases significantly increased all studied vegetative growth measurements as compared with control treatment. Obtained results may be due to the several reasons, like (1)- by direct reasons through that, diatoms contain organic compounds like protein, amino acids, growth regulators, carbohydrates, vitamins, minerals and especially silica ( amorphous silica) that can inter to plant from leaves surface through stomata or from roots. These can contribute in enhancing plant metabolism in turn produce vigor and strong tissues resistant to adverse environmental conditions (Mann and Stickle, 1997; Laing et al., 2006 and Vasanthi et al., 2014). (2)- Indirect reason through, the foliar spray treatments that mainly significantly reduced leaf-miner and aphids infestations and both early blight disease incidence and severity in turn enhancing plant characters. This result is compatible with finding pointed by Eileen and Sydney (2016) and Sarwar (2016).

Data showed that all vegetative growth measurements were significantly increased as a result of applied kaolinite and diatom sediments at rate of 2.5 and 5 ton/fed. of both. The results may be due to the role of kaolinite as a clay mineral and diatom sediments can enhance plant growth medium by (1)- Kaolinite has a very low cation exchange capacity (1 to 16 m.e./100 gm). The ability of kaolinite to hold positively charged plant nutrients is very limited. So, its ability to hold certain herbicides, insecticides and fungicides (Brown et al., 2010). This ability may contributed in plant resistance enhancement against insect pests attack and diseases infections in turn produced vigor plants. (2)- Diatom sediments contain materials back to death or stile life microorganisms, these materials definitely contain proteins, carbohydrates, fats, phenol compounds, vitamins, growth regulators, silica and minerals. These materials are release through soil solution to plants subsequently, to plant released bio-processes to produce strong plant resistance to pests, diseases and adverse environmental conditions.

Plant - nutrition balanced, healthy, vigor and free of pathogenic diseases and pest insects necessarily, produce a yield commensurate with its strength. Due to the strong correlation between yield and independent growth variables such as number of leaves, leaves area and number of tubers per plant as well as NAR and average of tuber weight, the yield and its 
components were in the same trend with growth parameters. Whatever, these results agree with those obtained by Javan et al. (2013), who found that number of seeds and number of pods per plant, weight of thousand seed, biological yield, seed yield and harvest index were significantly decreased in soybean plants treated with kaolin at concentration of $6 \%$.

\section{CONCLUSION}

In this study; leafminer and aphid insects furthermore early blight disease were integrated together as biotic stress to challenge the potato growth and productivity under the desert conditions. Particle film technology of kaolin or diatoms at 5\% were used as foliar spraying or as soil addition, or a combination with foliar spraying and soil addition has great potential for the control of insect population and rate of disease progress will be the most effective ecofriendly strategy to conserve the environment and produce an appreciated yield. These materials can be used also as new natural products for IPM programs in potato fields and needs further studies in the future. The result of foliar spray or soil addition indicated that potato yield and its components, as a general, are significantly affected with treatments. The effects were in the same vegetative growth results trend which due to the strong correlation between yield and independent growth variables such as number of leaves, leaves area and number of tubers per plant as well as NAR and average of tuber weight. This is a direct reaction to yield affecting by treatments while the indirect reactions were that the effect of treatments on insect pests and pathogenic diseases which cleared the correlation force between foliar spraying treatments and insect pests or pathogenic diseases. In generally, the research gave the promising use of diatoms and kaolin as one of the safety natural alternatives to protect plants from pests and diseases, increase yield and quality.

\section{REFERENCES}

Abdel-Razek, A.S., A.E. Abdel Salam and N.M. Abd El-Ghany (2014). Sustainable potato tuber moth, Phothoremia operculella (Zeller), control using biopesticides of natural and microbial origin. African J. Agric. Sci. Tech., 2 (6): 125-130.

Ali, E.A. (2016). Effectiveness of particle film technology and copper products in the control of olive fruit fly. J. Plant Prot. Path., Mansoura Univ., 7 (7): 439 - 444.

AOAC (1990). In "Official Methods of Analysis Association of Officinal Analytical Chemists". $16^{\text {th }}$ Ed. Washington, DC, USA.

Battarbee, R.W., V.J. Jones, R.J. Flower, N.G. Cameron, H. Bennion, Carvalho and S. Juggins (2001). In "Diatoms". (Last W.M., H.J.B. Birks and J.P. Smol eds.). Tracking Environmental 
Change Using Lake Sediments, Vol 3: Terrestrial, Algal, and Siliceous Indicators. Kluwer, Dordrecht, p. 155-202.

Brown, J.K., M. Rehman, D. Rogan, R.R. Martin and A.M. Idris (2010). First report of 'Candidatus Liberibacter psyllaurous' (syn. 'Ca. L. solanacearum') associated with 'tomato vein-greening' and 'tomato psyllid yellows'diseases in commercial greenhouse in Arizona. Plant Dis., 94: 376.

Bueno, A.F., B. Zechmann, W.W. Hoback, R.C. Bueno and O.A. Fernandes (2007). Serpentine leafminer (Liriomyza trifolii) on potato (Solanum tuberosum L.): field observations and plant photosynthetic responses to injury. Ciência Rural, Santa Maria, 37 (6): 1510-1517.

Canter-Lund, H. and J.W.G. Lund (1995). Freshwater algae their microscopic world explored. Biopress Bristol. Chemistry Research Journal, 1 (1): 50-57.

Crooks, R. and P. Prentice (2011). The benefits of silicon fertilizer for sustainably increasing crop productivity. The $5^{\text {th }}$ International Conference on Silicon in Agriculture, Beijing 2011.

Datnoff, L.E. and F.A. Rodrigues (2005). In "Role of Silicon in Suppressing Rice Diseases". APS News Releases.

Dixit, S.S., J.P. Smol, J.C. Kingston and D.F. Charles (1992). Diatoms: Powerful indicators of environmental change. Environmental Science and Technology, 26: 22-33.

Edward, B.R. and W.R David (2002). Aphid-transmitted potato viruses: The importance of understanding vector biology. A. J. Pot. Res., 79: 353-386.

Ehret, D.L., C. Koch, J. Menzies, P. Sholberg and T. Gavland (2001). Foliar sprays of clay reduce the severity of powdery mildew on long English cucumber and wine grapes. HortScience, 36: 934-936.

Eileen, A.B. and G.P. Sydney (2016). In "Natural Products for Insect Pest Management". University of Florida, IFAS, Florida A. \& M. University Cooperative Extension Program.

FAO (2012). The state of food insecurity in the world. Rome.

Fauteux, F., W. Remus-Bore, J.G. Menzies and R.R. Belanger (2005). Silicon and plant disease resistance against pathogenic fungi. FEMS Microbiol. Lett., 249: 1-6.

Gindaba, J. and S.W. Wand (2007). Climate-ameliorating measures influence photosynthetic gas exchange of apple leaves. Ann. Appl. Biol., 150: 75-80.

Glenn, D.M., N. Cooley, R. Walker, P. Clingeleffer and K. Shellie (2010). Impact of kaolin particle film and water deficit on wine grape water use efficiency and plant water relations. HortScience, 45 (8): 1178-1178. 
Jackson, M.E. (1962). In "Soil Chemical Analysis". Constable and Company Ltd., Eondon, 448 pp.

Jalali, A.H. (2013). Potato (Solanum tuberosum L.) yield response to simulated hail damage. Archives of Agronomy and Soil Science, 59 (7): 981-987.

Javan, M., M. Tajbakhsh and B.A. Mandoulakani (2013). Effect of antitranspirants application on yield and yield components in soybean (Glycine max L.) under limited irrigation. JABS, 7 (1): 70-74.

Koivunen, M.S., C.C. Joel and J.B. John (2013). In "Pest Management with Natural Products". Available online:| http://pubs.acs.org | doi: 10.1021/bk-2013-1141.ch001 Pest Management with Natural Products (Beck, J., et al. eds.). ACS Symposium Series; American Chemical Society, Washington, DC.

Kroschel, J., Sporleder, M., H.E.Z. Tonnang, H. Juarez, , P. Carhuapoma, J. C. Gonzales and R. Simon (2013). Predicting climate change caused changes in global temperature on potato tuber moth Phthorimaea operculella (Zeller) distribution and abundance using phenology modeling and GIS mapping. Journal of Agricultural and Forest Meteorology, 170: 228-241.

Laing, M.D., M.C. Gatarayiha and A. Adandonon (2006). Silicon use for pest control in agriculture - a Review. Proc. S. Afr. Sug. Technol. Ass., 80: 278.

Lamb, E.M., N.E. Rosskopf and C. Koblegard (2002). Use of kaolin clay for disease control in greenhouse cucumbers. Proc. Fla. State Hort. Soc., 115: 180-182.

Liang, G.M. and T.X. Liu (2002). Repellency of a kaolin particle film, Surround, and a mineral oil, sun spray oil, to silver leaf whitefly (Homoptera: Aleyrodidae) on melon in the laboratory. J. Econ. Entomol., 95: 317-324.

Linker, H.M., D.B. Orr and M.E. Barbercheek (2000). In "Insect Management on Organic Farms". Available online: www.cefs.edu, $37 \mathrm{pp}$.

Maketon M., P. Orosz-Coghlan and D. Hotaga (2008). Field evaluation of metschnik off (Metarhizium anisopliae) sorokin in controlling cotton jassid (Amrasca biguttula biguttula) in aubergine (Solanum aculeatissimum). Int. J. Agric. Biol., 10 (1): 47-51.

Mann, D. and A.J. Stickle (1997). Sporadic evolution of dorsoventrality in raphid diatoms, with special reference to Lyrella amphoroides sp. nov. Nova Hedwigia, 65: 59-77.

Marco, S., D. Ziv and R. Cohen (1994). Suppression of powdery mildew in squash by applications of whitewash, clay and antitranspirant materials. Phytoparasitic, 22: 19-29. 
Markó, V., L.H.M. Blommers, S. Bogya and H. Helsen (2008). Kaolin particle films suppress many apple pests, disrupt natural enemies and promote woolly apple aphid. J. Appl. Entomol., 132: 26-35.

Menzies, J.G., Ehret D.L., Glass A.D.M., T. Helmer, C. Koch and F. Seywerd (1991). Effects of soluble silicon on the parasitic fitness of Sphaerotheca fuliginea on Cucumis sativus. Phytopathology, 81: 84-88.

Mohadeseh, N., F. Paknejad and M. Moarefi (2013). Effect of concentrations and time of kaolin spraying on wheat aphid. J. Biol. Environ. Sci., 7 (21): 163-168.

Palumbo, J.C. (2012). Insect management on desert produce crops: leafminers. Veg. IPM, 3 (21): 17- 20.

Piper, S.S. (1950). In "Soil and Plant Analysis". Univ. Inter Sci. publishers, Inc., New York. Adelaide, p. 258-275.

Qureshi, M.A. (2014). In "Integrated Pest Management Training Manual for Potato Farmers". Published by The Agribusiness Project, with the funding support of United States Agency for International Development, under Agribusiness Support Fund, Pakistan. CIPM - Islamabad, Pakistan.

Raziq, F. and S. Ishtiaq (2010). Integrated control of Alternaria solani with Trichodermaspp and fungicides under in vitro conditions. Sarhad J. Agric., 26 (4): 613-619.

Reitz, S.R., G. Maiorino, S. Olson, R. Sprenkel, A. Crescenzi and M.T. Momol (2008). Integrating plant essential oils and kaolin for the sustainable management of thrips and tomato spotted wilt on tomato. Plant Dis., 92: 878-886.

Richards, L.F. (1954). In "Diagnosis and Improvement of Saline and Alkaline Soils". Agric. Hand Book, USA, 60 pp.

Sarwar, M. (2016). Inorganic insecticides used in landscape settings and insect pests. Chemistry Research Journal, 1 (1): 50-57.

Seebold, K.W., T.A. Kucharek, L.E. Datnoff, F.J. Correa-Dictoria and M.A. Marchetti (2001). The influence of silicon on components of resistance to Blast susceptible, partially resistant and resistant cultivars of rice. Phytopathology, 91: 63-69.

Sharaby, A., H. Abdel-Rahman and S.S. Moawad (2015). Intercropping system for protection the potato plant from insect infestation. Ecological Balkanica, 7 (1): 87-92.

Singh, R.S. (2004). In "Introduction to Principles of Plant Pathology". $4^{\text {th }}$ Ed., Oxford and IBH Publication, Pvt. Ltd., New Delhi India.

Steiman, S.R. and H.C. Bittenbender (2007). Analysis of kaolin particle film use and its application on coffee. Hortscience, 42 (7): 16051608 . 
Thomas, M.L. and F.G. Hills (1975). In "Statistical Methods in Agric. Research". Univ. of California, Davis 95616, $2^{\text {nd }}$ Printing, p. 6774.

Topps, J.H. and R.L. Wain (1957). Investigation on fungicides III the fungi toxicity of 3 and 5-alkyl-salicyl-anilides and $\mathrm{P}-$ chloroanilines. Ann. Appl. Biol., 45 (3): 506-511.

Torlon, J.L., R.J. Heckman, J.E. Simon and C.A. Wyenandt (2016). Article silicon soil amendments for suppressing powdery mildew on pumpkin. Sustainability, 8: 293.

Unruh T.R., A.L. Knight, J. Upton, D.M. Glenn and G.J. Puterka (2000). Particle film for suppression of the codlingmoth, Cydia pomonella (Lepidoptera: Totricidae), in apple and pear orchards. J. Econ. Entomol., 93: 737-743.

Van der Walls, J.E., L. Korsen, T.A.S. Aveling (2001). A review of early blight of potato. Afr. Plant Protec., 70: 91-102.

Vasanthi, N., L.M. Saleena and R.S. Anthoni (2014). Silicon in crop production and crop protection-A Review. Agri. Reviews, 35 (1): 14-23.

Vincent, C., G. Hallman, B. Panneton and F. Fleurat-Lessard (2003) Management of agricultural with physical control methods. Annu. Rev. Entomol., 48: 261-81.

Watson, D.T. (1947). Comparative physiological studies on the growth of yield crops I. Variation in net assimilation rate and leaf area between species and varieties and between yields. Am. Bot. (N.S.), 11: 41-76. 


\section{تأثير الكاولين والدياتومات على نمو وانتاجية وآفات البطاطس تحت ظروف شمال سبناء \\ خالد عوض الله أحمد صبيح'، عصام أحمد علي ب* وعبير المرسي أحمد الحديدي r} 'قسم الإنتاج النباتي، مركز بحوث الصحر اء، المطرية، القاهرة، مصر

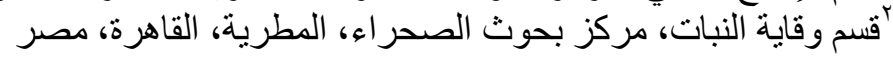

يهدف البحث إلى دراسة تأثير المعاملات الأرضية بمعدن الكاؤولينيت ورواسب

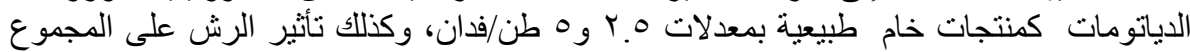

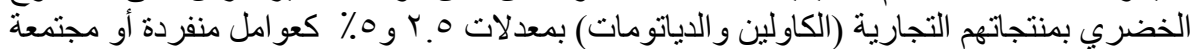
على نباتات البطاطس Solanum tuberosum L. صنف دياموند لمقاومة بعض الته الآفات التي تصيب نباتات البطاطس؛ مثل حشرة صانعات الأنفاق Liriomyza huidobrensis وحشرة المن و و مرض اللفحة المبكرة Alternaria solani persica

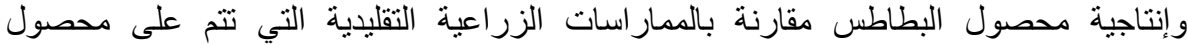
البطاطس. وقد تم تتفيذ التجربة تحت ظروف المناطق الصحراوية بسيناء بإستخدام التصميم الإحصائي القطاعات المنشقة.

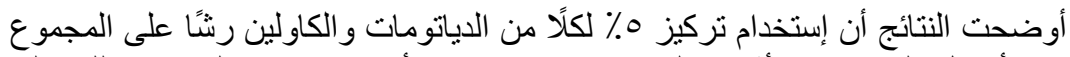

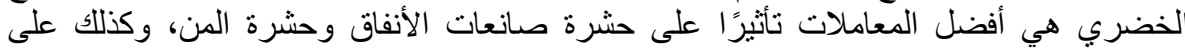

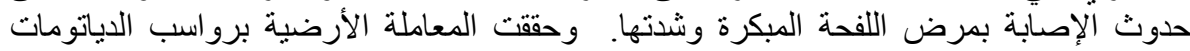

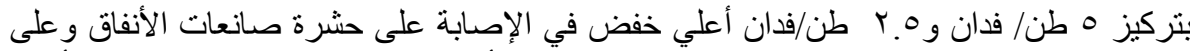

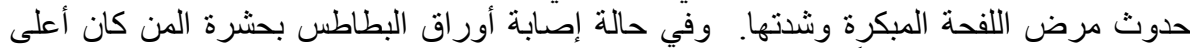

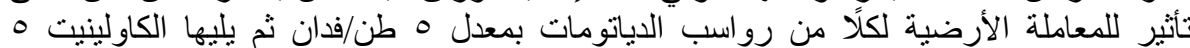

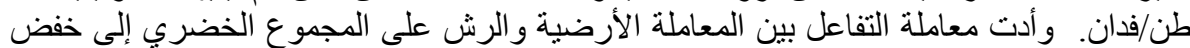

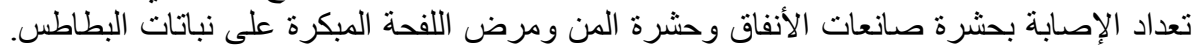

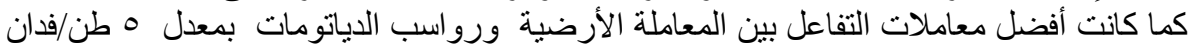

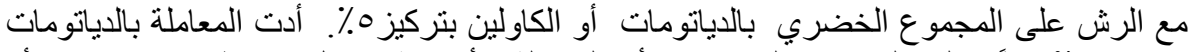

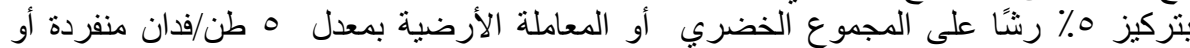
مجتمعة إلى التأثير المعنا والجاف للنبات بالإضافة إلى دليل مساحة الورقة وصافي الإني معدل التمثيل الضونئي) ومحتوى

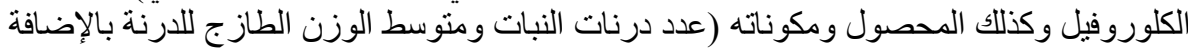

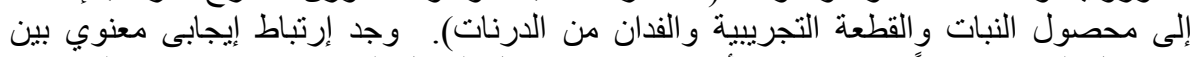

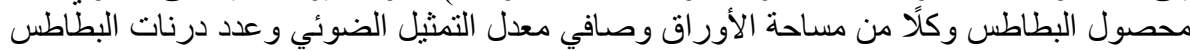

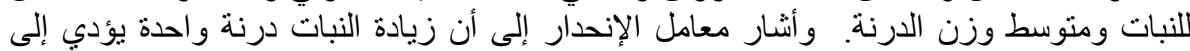

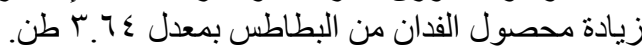

Egyptian J. Desert Res., 67, No. 1, 83-115 (2017) 